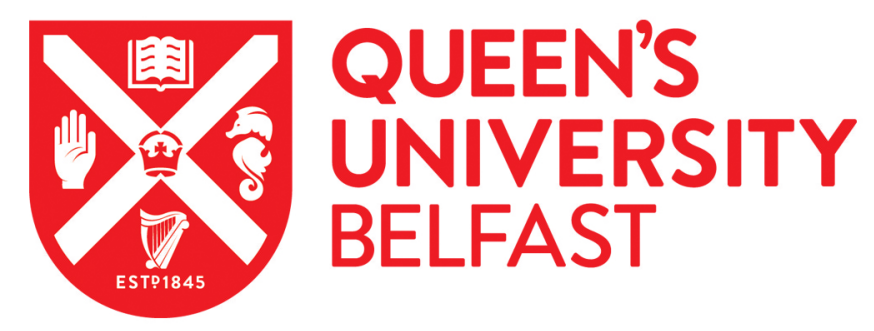

\title{
Optimisation of rheological parameters, induced bleeding, permeability and mechanical properties of supersulfated cement grouts
}

Sonebi, M., Abdalqader, A., Fayyad, T., Perrot, A., \& Bai, Y. (2020). Optimisation of rheological parameters, induced bleeding, permeability and mechanical properties of supersulfated cement grouts. Construction and Building Materials, 262, 1-16. https://doi.org/10.1016/j.conbuildmat.2020.120078

\section{Published in:}

Construction and Building Materials

\section{Document Version:}

Publisher's PDF, also known as Version of record

\section{Queen's University Belfast - Research Portal:}

Link to publication record in Queen's University Belfast Research Portal

\section{Publisher rights}

Copyright 2020 Elsevier.

This manuscript is distributed under a Creative Commons Attribution-NonCommercial-NoDerivs License

(https://creativecommons.org/licenses/by-nc-nd/4.0/), which permits distribution and reproduction for non-commercial purposes, provided the author and source are cited.

\section{General rights}

Copyright for the publications made accessible via the Queen's University Belfast Research Portal is retained by the author(s) and / or other copyright owners and it is a condition of accessing these publications that users recognise and abide by the legal requirements associated with these rights.

Take down policy

The Research Portal is Queen's institutional repository that provides access to Queen's research output. Every effort has been made to ensure that content in the Research Portal does not infringe any person's rights, or applicable UK laws. If you discover content in the

Research Portal that you believe breaches copyright or violates any law, please contact openaccess@qub.ac.uk. 


\title{
Optimisation of rheological parameters, induced bleeding, permeability and mechanical properties of supersulfated cement grouts
}

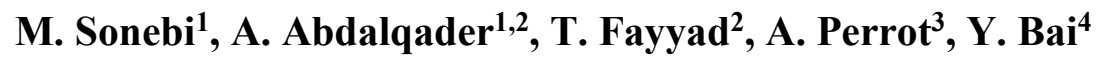 \\ ${ }^{1}$ School of Natural and Built Environment, Queen's University Belfast, Belfast, Northern Ireland, UK \\ ${ }^{2}$ Tracey Concrete Ltd, Northern Ireland, UK \\ ${ }^{3}$ University Bretagne Sud, Lorient, France \\ ${ }^{4}$ Departement of Civil Engineering, Environmental and Geomatic, University College London, UK
}

\section{Abstract}

Presenting a promising option that could be used to encapsulate nuclear waste material for disposal, supersulfated cement (SSC) is, again, receiving wide attention among research community as a cementitious system that has noteworthy properties. It is also an environmentally friendly cement since it is mainly composed of ground granulated blast furnace slag (GGBS) that is activated by a sulphate source such as gypsum, hemihydrate or anhydrite. Although there is some research on SSC, little research work has focused on modelling the effects of the various parameters using a statistical approach which is the aim of this paper. The effect of dosages of GGBS, anhydrite (ANH) and water-to-binder ratio (W/B) on the fresh and rheological parameters, induced bleeding, permeability, compressibility, and compressive strength of supersulfated grouts was investigated. Then, statistical models and isoresponse curves were developed to capture the significant trends of the tested parameters using factorial design approach. The models suggested that that W/B had significantly higher influence on most of the parameters tested while the influence of GGBS and ANH and their interactions varied depending on the parameter in question. . The findings of this study show the importance of understanding the role of and optimising the relevant key factors in producing SSC fit-for-purpose. The statistical models developed in this paper can facilitate optimizing the mixture proportions of grouts for target performance by reducing the number of trial batches needed.

Keywords: compressive strength, heat of hydration, permeability, induced bleeding, rheology, slump flow, supersulfated cement, yield stress, viscosity 
- SSC presents a promising option to encapsulate nuclear waste material.

-The constituents' effect on SSC grouts' properties was studied and modelled.

-Factorial design is a powerful tool for optimizing the mixture proportions of SCC.

-W/B had the highest influence on most of the parameters tested.

\section{Introduction}

Ancient concrete as well as more recent concrete materials reinvented in the nineteenth century have performed well in the past. However, over recent decades, a great challenge had emerged regarding ensuring efficient consumption of natural resources and, hence, there was a pressure to make construction industry more sustainable. Concrete is widely used within the construction industry and contributes to a large extent to the global energy consumption and carbon emission due to the energy intensity and $\mathrm{CO}_{2}$ emissions associated with cement production. So the industry was looking for ways to become more sustainable [1]. This has resulted in a high demand for new types of cement possessing improved qualities including strength, toughness, and durability as well as being environmentally friendly.

Cements made of industrial waste materials and by-products emerged as one of the sustainable options to traditional Portland cement (PC) because it is mainly manufactured using waste and by-products that require little processing; making the embodied energy and emissions associated with the production process low. Besides its environmental benefits, such materials has a great versatility depending on their components and they can be tailored to make them suitable for a wide range of applications in the structures industry [2].

One of these environmentally friendly cements that was used during the last decades is the supersulfated cement (SSC) which is a cementitious system composed of ground granulated blast furnace slag (GGBS) that is activated by a sulphate source such as gypsum, hemihydrate or anhydrite [3]. Wastes of semi-dry and dry flue gas desulpherisation (FGD) can be used as source of sulphate $[4,5]$. SSC has great advantages that make it attractive for use; firstly, it is mainly manufactured using by-products and industrial wastes. Secondly, it has lower $\mathrm{CO}_{2}$ emissions compared to PC because clinker burning is reduced. The estimated embodied $\mathrm{CO}_{2}$ of GGBS is $79.6 \mathrm{kgCO}_{2}$ /tonne which is 10 times lower than that of Portland cement (CEM 1) at $860 \mathrm{kgCO}_{2} /$ tonne [6]. Besides that, SSC produces much lower heat than PC; and also, SSC 
has superior resistance to chemically aggressive environments such as sulfates. Due to the glassy nature of GGBS, composed mainly of monosilicates, GGBS easily dissolves in low to mild alkaline solutions. However, it is required that the alumina content $\left(\mathrm{Al}_{2} \mathrm{O}_{3}\right)$ of slag to be no less than $13 \%$ to be used effectively in SSC [7]. The most commonly used sources of sulphate is anhydrite because it has lower solubility rate than other sources $[8,9]$. To promote the dissolution of slag, PC is added because its hydration yields the formation of calcium hydroxide $(\mathrm{CH})$ which provides the required alkaline environment for slag dissolution. Once the slag is dissolved, the released aluminium, silicon and calcium ions from slag glass react with the calcium sulfate present in the mixture to form two main hydration products: ettringite $\left(\mathrm{C}_{6} \mathrm{~A} \check{S}_{3} \mathrm{H}_{32}\right)$ and calcium silicate hydrate $(\mathrm{C}-\mathrm{S}-\mathrm{H})$ [10]. Ettringite provides the early strength to SSC mixtures contributing to the strength development while C-S-H is responsible for later strength and the continual increase of strength over time [11, 12]. C-S-H formed in SSC has a $\mathrm{Ca} / \mathrm{Si}$ ratio between 1.0 and 1.2, which is much lower than that formed in PC mixtures [13]. This means that the chemical composition of slag plays a significant role on the strength development, dissolution of the slags and the amount of hydration products formed.

After being used for long time in construction for special structures, currently, SSC is very rarely used and no longer produced in some areas. According to Baux et al. [14] this happened because of its lack of reactivity. Grounds et al. [10] believed that this is because there is uncertainty over some of its properties which include its long-term stability and durability. One of their main concern surrounding SSC is due to the hydration product ettringite or trisulphoaluminate which is known to be unstable in Portland cement and has been found to be expansive in certain environments. Phelipot-Mardelé et al. [15] state that this could be because, generally, cement made with blast furnace slag tends to harden more slowly than mortar and concrete made from PC.

The nuclear power is a promising option for the future in the UK and the world in general, however, the nuclear waste is still an obstacle in its way to be a vital option for the future and to gain public acceptance [16]. This can be achieved by making the contaminants to be less mobile or less toxic by 'waste stabilization' that results in converting the contaminants from the dissolved phase to a solid phase by reactions such as precipitation, sorption or substitution. This prevents the waste from diffusion to the external environment [16, 17]. Most applications of stabilization are cement-based where the cement forms a low permeability matrix and where the contaminant is incorporated into hydrated phases and then precipitated due to the prevailing $\mathrm{pH}$ in the pore solution [18]. This means that the efficiency of the process depends on the 
prevailing $\mathrm{pH}$. The $\mathrm{pH}$ resulting from cement hydration results in many metal contaminants forming hydroxide or mixed hydroxide solids [17]. Portland cement will tend to result in a higher $\mathrm{pH}$ while combining it with lime as well as fly ash, blast furnace slag, and other pozzolanic binders will result in lower $\mathrm{pH}$. The interactions of these binders with waste components determine the extent of treatment [18].

There is a lack of data detailing the assessment criteria and performance of nuclear encapsulation grout/concrete. However, general requirements of a cementitious system for encapsulation can be summarised as follows: an ability to incorporate waste and harden; fluidity of initial cemented mix and potential for remote mixing; low permeability; resistance to water; low temperature rise on setting; workable setting time; low free or unbound water when setting reaction is complete; low internal $\mathrm{pH}$ to avoid ongoing reactions such as corrosion; long term durability [16].

The solubility of many heavy metals is low at low $\mathrm{pH}$, and therefore low $\mathrm{pH}$ cements, such as SSC, are likely to be particularly desirable cements for nuclear waste management [16-19]. This would help to make the nuclear energy, as a clean and a safe source of energy, a promising alternative for future generations. This, again, has highlighted some of the noteworthy properties of the SSC where not only the $\mathrm{pH}$ value that makes SSC a promising option that could be used to encapsulate nuclear waste material for disposal. Also, the heat of hydration in supersulfated cement is much lower than that of OPC and therefore the heat gradient created during hydration between the internal and external surfaces would not be as great and thus less stress caused and less chance of cracking which would be unacceptable with nuclear waste disposal. It has high non-evaporable water content, that is, it's chemically bonded to the silica. Besides that, it has a good durability in aggressive environments, such as structures exposed to seawater or sulfate-bearing groundwater [9, 14, 15, 20-22].

These technical and environmental benefits have re-simulated recent research on this type of cement and brought the attention for re-investigating overcoming its drawbacks to offer a green cement for very essential applications.

Currently, different researches are being carried out on SSC in order to optimize the usage of SSC. Many researchers have examined its various mixture compositions to determine the best compositions for some desirable properties, such as strength, low permeability, faster setting time, etc. A research on slags activated with $15-20 \%$ calcium sulfate showed a higher compressive strength in comparison with other mixtures when they examined slags classified 
as low-lime high-alumina and when various SSC mixture compositions were examined, with 70-85\% slag, 10-25\% anhydrite, and 5\% Portland cement for alkali activation [15]. Gruskovnjak et al. [8] investigated the effect of alumina content in the slag by examining two types of slag with a high $\mathrm{Al}_{2} \mathrm{O}_{3}$ percentage content (12\%) and low $\mathrm{Al}_{2} \mathrm{O}_{3}$ percentage content (7.7\%). The findings of their study showed that slag with high alumina contents produced more ettringite and higher strength. This was attributed to the higher dissolution rate of high alumina slag. SSC hydration characteristics with different fineness has also been investigated [20]. It showed that when sample particles become finer, the compressive strength is significantly higher. Also, there is some work, which has been done on modifying the mechanical properties of SSC with addition phosphogypsum $[19,23]$. Recently, the influence of curing temperature was studied for supersulfated cements made with two slags having different chemical compositions [20]. It was found that SSC made with high-alumina slag resulted in higher strengths and presented a more complex mechanism of hydration that was strongly influenced by the solubility of anhydrite. This is also being shown in [21] where the SSC made using highalumina slag exhibited higher compressive strength and the use of higher activator contents decreased the compressive strength.

Based on recent researches and the fact that there are many factors and parameters involved in the composition of SSC, there is a demanding need for optimizing the cement grout in order to effectively utilise it to fit for purpose. The current paper aligns with this demand. The effect of GGBS, water-to-binder ratio W/B, and anhydrite dosages on the grout fluidity, rheological properties, induced bleeding, fresh state permeability and compressibility, maximum heat of hydration and compressive strength will be investigated using factorial design approach and analysis. Although there is some research on SSC, little research work has focused on modelling the effects of the various parameters using a statistical approach. Factorial design is a powerful tool and widely used in experiments involving many factors. It can be utilised to study the joint effect of factors on responses or dependent variables, and, to develop models applicable to design and development of experiments. Simulation of models obtained with factorial design can facilitate the test protocol needed to optimize cement grout within a given set of performance criteria. 


\section{Experimental Programme}

157

158

159

160

161

162

163

164

165

166

167

Table 1. Chemical and physical properties of cement and GGBS

\begin{tabular}{ccc}
\hline \multirow{2}{*}{ Chemical analysis } & \multicolumn{2}{c}{ Material } \\
\cline { 2 - 3 } & CEM I & GGBS \\
\hline $\mathrm{SiO}_{2}(\%)$ & 21.01 & 35.18 \\
$\mathrm{Al}_{2} \mathrm{O}_{3}(\%)$ & 4.92 & 13.96 \\
$\mathrm{Fe}_{2} \mathrm{O}_{3}(\%)$ & 2.84 & 0.25 \\
$\mathrm{MgO}(\%)$ & 2.20 & 8.18 \\
$\mathrm{CaO}(\%)$ & 64.52 & 41.21 \\
$\mathrm{Na} 2 \mathrm{O}(\%)$ & 0.20 & 0.19 \\
$\mathrm{~K}_{2} \mathrm{O}(\%)$ & 0.71 & 0.42 \\
$\mathrm{SO}_{3}(\%)$ & 2.53 & -- \\
$\mathrm{P}_{2} \mathrm{O}_{5}(\%)$ & 0.11 & -- \\
$\mathrm{LOI}(\%)$ & 1.26 & 0.64 \\
\hline Physical analysis & & \\
\hline Specific gravity & 3.08 & 2.91 \\
Specific surface area $\left[\mathrm{m}^{2} / \mathrm{kg}\right]$ & 360 & 600 \\
\hline
\end{tabular}

Table 2. Mix proportions for the grouts used in the factorial design

\begin{tabular}{ccccccc}
\hline Mix & \multicolumn{3}{c}{ Code } & \multirow{2}{*}{ W/B } & \multicolumn{2}{c}{ Percentage (\%) } \\
\cline { 2 - 3 } No. & W/B & GGBS & ANH & & GGBS & ANH \\
\hline M1 & -1 & -1 & -1 & 0.34 & 60 & 0 \\
M2 & 1 & -1 & -1 & 0.44 & 60 & 0 \\
M3 & -1 & 1 & -1 & 0.34 & 60 & 20 \\
M4 & 1 & 1 & -1 & 0.44 & 60 & 20 \\
M5 & -1 & -1 & 1 & 0.34 & 80 & 0 \\
M6 & 1 & -1 & 1 & 0.44 & 80 & 0 \\
M7 & -1 & 1 & 1 & 0.34 & 80 & 20 \\
M8 & 1 & 1 & 1 & 0.44 & 80 & 20 \\
M9 & 0 & 0 & 0 & 0.39 & 70 & 10 \\
M10 & 0 & 0 & 0 & 0.39 & 70 & 10 \\
M11 & 0 & 0 & 0 & 0.39 & 70 & 10 \\
M12 & 0 & 0 & 0 & 0.39 & 70 & 10 \\
\hline
\end{tabular}


All grout mixes were prepared in $2 \mathrm{~L}$ batches using a high-shear mixer with a $4.5 \mathrm{~L}$ capacity. The mixing water was kept at $9.8 \pm 0.2{ }^{\circ} \mathrm{C}$ to compensate for heat generated during mixing. The cement and GGBS were mixed with ANH in a sequence that started with adding all of the water into the mixer. After one minute, the binder was gradually introduced. The grout was mixed for one minute, followed by 30 seconds of rest. Subsequently, the grout was mixed again for $2 \mathrm{~min}$ at a high speed $(285 \mathrm{rpm})$ and for $1 \mathrm{~min}$ at the low speed (140 rpm).

For all tests the timing is given from zero time, i.e. the time when the cement particles first touch the mixing water. The mini-slump flow test started at 7 min (immediately after the end of mixing). The transparent cone-shaped mould described elsewhere [24] was placed in the centre of a smooth Plexiglas plate. After filling with grout, the cone was gently lifted (approximately $30 \mathrm{~s}$ after placement of the grout). When the flow stopped, the spread of the grout was measured with a ruler in two perpendicular directions.

Marsh cone test was carried out using a metal cone with an orifice diameter of $10 \mathrm{~mm}$ and started at $8 \pm 1 \mathrm{~min}$. One litre of grout was poured into the cone. The cone's orifice was opened $15 \mathrm{~s}$ after pouring the cement grout into the cone. The time taken for each $100 \mathrm{ml}$ of grout to flow through the orifice was recorded, and the measurements were completed upon collecting $700 \mathrm{ml}$ of grout.

The viscosity of cement grout was determined using a coaxial rotating cylinder viscometer Fann (smooth cylinders, no serration) that determined apparent viscosity at different shear rates. The test was contained in the annular space between an outer cylinder (rotor) with a radius of $18.415 \mathrm{~mm}$ and a bob with a radius of $17.245 \mathrm{~mm}$ and a height 0 and bob were plunged into a cup containing $350 \mathrm{ml}$ of sample grout. Viscosity measurements were made when the outer cylinder, rotating at a known speed, caused a viscous drag to be exerted by the fluid. This drag created a torque on the bob, which was transmitted to a precision spring, where its deflection was measured and compared with test conditions and the instrument's constants. The measurement was made for 12 rotor speeds from $0.9 \mathrm{rpm}$ to 600 rpm, where the viscometer reading values $(\theta)$ were recorded. The value of shear stress $\tau(\mathrm{Pa})$ was calculated by including $\mathrm{k}_{1}$, torsion constant of spring per unit deflection $(\mathrm{N}-\mathrm{cm} / \mathrm{degree})$, $\mathrm{k}_{2}$, shear stress constant for the effective bob surface $\left(\mathrm{cm}^{-3}\right)$ and $\mathrm{k}_{3}$, shear rate constant $\left[\mathrm{s}^{-1} / \mathrm{rpm}\right]$ $[25,26]$.

Rotor speed was increased step by step, and the viscometer readings were recorded with increasing rotation speeds. The $\theta$ reading was taken when the needle in the viscometer was 
stabilised, or 30 seconds after the change of speed in cases when the needle had not stabilised due to the thixotropy of the cement grout. The time of $\theta$ reading was generally between 5 and 10 seconds.

In this study, the down-curve was chosen for final evaluation because it offered a better description of the rheological behaviour of the grouts, including a structural breakdown phenomenon of inner forces among particles [27]. The values of shear yield stress (the minimum shearing stress required for the fluid to start flowing) and plastic viscosity used the modified Bingham model [28] and are expressed as follows:

$\tau=\tau_{0}+\mu_{p} \dot{\gamma}+c \dot{\gamma}^{2}$

Where $\tau_{0}$ is yield stress $(\mathrm{Pa}), \mu_{\mathrm{p}}$ is plastic viscosity $(\mathrm{Pa} \cdot \mathrm{s}), \dot{\gamma}$ is shear rate $\left(\mathrm{s}^{-1}\right)$, and $\mathrm{c}$ is a constant.

The cohesion of grout was determined at $30 \pm 1$ min with a Lombardi plate cohesion meter [29]. A thin galvanized steel plate $(100 \times 100 \times 1 \mathrm{~mm})$ was immersed in the grout and hung on a stand placed on an electronic balance. The weight of the grout still present on the plate was recorded when the dripping of the grout had stopped. This test was followed by the fresh density measurement of the grout with a mud balancer. Knowing the fresh density of the grout, it was possible to calculate the thickness on each side of the plate.

The resistance of the fresh grout to induced bleeding was evaluated using a pressure filter. The equipment consists of a pressure vessel, filter paper, which is placed on a sieve, and a graduated cylinder. A $200 \mathrm{ml}$ grout sample is placed in the pressure vessel. After closing the cell, the graduated cylinder is placed under the outlet of the cell. The cell is pressured by compressed air to $0.55 \mathrm{MPa}$. The volume of water going out through the outlet on the bottom of the cell is recorded at 15 and $30 \mathrm{~s}$, then at every minute up to $10 \mathrm{~min}$, and then at every $5 \mathrm{~min}$ up to $30 \mathrm{~min}$ [25].

Considering homogeneous bleeding, the results of the induced bleeding tests allow to derive the evolution of the permeability of the sample during its compaction under the applied pressure. The permeability of the material is directly linked to the bleeding rate during the material consolidation until the tested material is able to sustain the applied pressure [30, 31]. It refers to the material ability to slow down the water filtration process.

The measurement of the flow water allows to compute instantaneous W/B ratio and makes it possible to link it with the computed instantaneous permeability at a given time of the test [32- 
34]. IThe water flow is computed by dividing the variation of the measured water mass flowing out the samples by the elapsed time between two successive data sampling. In this study, value of permeability at 1 and 30 minutes are taken and compared. It corresponds to the initial and final permeability of the mixes.

The material compressibility is considered in a soils mechanics way [30, 35]. It corresponds to the ratio of the variation of void ratio (liquid/solid volume ratio) to the variation of logarithm of applied pressure between the initial and the final state of the induced bleeding test. It provides the equilibrium state of the sample under a given applied pressure and is valid for both homogeneous and heterogeneous bleeding [36].

It is worth noting that the computed permeability describes homogeneous bleeding kinetics while compressibility describes the amplitude of the bleeding phenomenon.

Heat of hydration was evaluated by isothermal calorimetry with an eight-channel heat conduction calorimeter maintained at $22^{\circ} \mathrm{C}$. This equipment measures heat evolved by comparing the temperatures of a grout sample and an inert reference which are both held under isothermal conditions. The heat flow results are recorded as a function of time. CEM I, GGBS and ANH were blended manually for $30 \mathrm{~s}$. After the addition of water, the grout was blended $10 \mathrm{~s}$ by hand and then an additional $50 \mathrm{~s}$ mechanically. Polyethylene ampoules were filled with approximately $6 \mathrm{~g}$ of each grout, and the experiments were conducted for at least $72 \mathrm{~h}$.

The compressive strength of the grout was determined by crushing three cubes of $50 \mathrm{~mm}$ size. After casting, the samples were covered with a polymer sheet (a cling film) to limit evaporation of water and stored in a conditioning room at $20 \pm 2{ }^{\circ} \mathrm{C}$ for $24 \pm 0.5$ hours. Afterwards, cubes were demoulded and placed in water at $20 \pm 1{ }^{\circ} \mathrm{C}$ until tested at $1,3,7$, and 28days.

In order to perform the $\mathrm{pH}$ test a powder sample of the hardened mixes was required. The test was performed on 1, 7 and 28 day samples. As mixes 9-12 are of identical composition, the reason is explained later in 4.1 derived statistical model, tests were only performed on sample 10. To get the powder with a fineness of $65 \mu \mathrm{m}$ the samples were firstly drained of the acetone. To remove any remaining acetone, they were placed in a vacuum desiccator. The pieces were then ground using a mortar and pestle, passed through a $65 \mu \mathrm{m}$ sieve, placed in sample bags and returned to the desiccator. The samples had then to be mixed with distilled water to enable the $\mathrm{pH}$ test to be performed. A 1:10 ratio of cement to water was used and mixed for 24 hours using a rotating machine. To get the $\mathrm{pH}$ reading the samples were put into a centrifuge machine to separate the solid and liquid. At this stage the solution should have a pH equivalent to cement 
it was mixed with. To get a $\mathrm{pH}$ reading for the samples, a $\mathrm{pH}$ device was used where a probe is placed in the solution. The machine was calibrated with three buffer solutions of 7, 10 and $13 \mathrm{pH}$ levels before measuring the $\mathrm{pH}$ of the samples.

SEM (scanning electron microscopy) was carried out using a JEOL JSM6400 on flat fractured surface specimens obtained from compression testing at 7-day samples. Prior to SEM testing, the samples were mounted onto metal stubs using carbon paste and coated with gold film to ensure good conductivity. The accelerated voltage was set at $20 \mathrm{kV}$.

\subsection{Statistical Design and Modelling of Experiments}

The technique of analysis used in this study was a $2^{\mathrm{k}}$ factorial experimental design [37] to evaluate the influence of two different levels (maximum and minimum) for each variable on the relevant grout properties. Three key parameters (W/B, ANH, GGBS) that should have significant influence on mix characteristics of supersulfated cements were selected to formulate the mathematical models for evaluating relevant properties (i.e. $\mathrm{k}=3$ in this study, thus the total mixes for the factorial design was $2^{3}=8$ ). Additionally, a mix at the central point was replicated four times to estimate the experimental error and improve the reliability of the models. The coding and levels of the variables (W/B, and dosages of GGBS and ANH) are given Table 2.

The statistical models are valid for supersulfated grout (SSC) mixes made with W/B, GGBS and $\mathrm{ANH}$ in the ranges of 0.34 to $0.44,60 \%$ to $80 \%$ and $0 \%$ to $20 \%$, respectively. The modelled experimental region consisted of mixtures ranging from coded variables of -1 to +1 . The coded factors for variables were calculated by:

Coded Factor $=($ Actual value-Factor means $) /[$ Range of factor value/2 $]$

Hence:

Coded W/B $=($ Actual W/B -0.39$) / 0.05$

Coded GGBS $=($ Actual GGBS -0.7$) / 0.1$

Coded Anhydrite $=($ Actual ANH -0.1$) / 0.1$

The responses modelled were mini-slump, plate cohesion, Marsh cone, yield stress, plastic viscosity, induced bleeding at $1 \mathrm{~min}, 5$ and $30 \mathrm{mins}$, permeability at $1 \mathrm{~min}$ and $30 \mathrm{mins}$, compressibility and compressive strength at 1, 3, 7 and 28 days. The general model associated 
with the two-level factorial design incorporating three independent variables (W/B, GGBS, $\mathrm{ANH}$ ) is expressed by:

$$
\mathrm{Y}_{1}=\mathrm{a}_{0}+\mathrm{a}_{1} \cdot \mathrm{W} / \mathrm{B}+\mathrm{a}_{2} \cdot \mathrm{GGBS}+\mathrm{a}_{3} \cdot \mathrm{ANH}+\mathrm{a}_{4} \cdot \mathrm{W} / \mathrm{B} \cdot \mathrm{GGBS}+\mathrm{a}_{5} \cdot \mathrm{W} / \mathrm{B} \cdot \mathrm{ANH}+\mathrm{a}_{6} \cdot \mathrm{GGBS} \cdot \mathrm{ANH}
$$

+ a 7 W/B.GGBS.ANH $+\varepsilon$

where,

$\mathrm{Y}_{1}$ : Response (mini slump, marsh cone, plate cohesion, etc.)

$\mathrm{a}_{0}$ : Overall mean factor effect

$\mathrm{a}_{1}$-a7: Regression coefficients representing model constants (contribution of independent variables and their interaction to each response)

a1.W/B, a2.GGBS, a3.ANH: Linear effect of factors W/B, GGBS and ANH

a4.W/B.GGBS, a5.W/B.ANH, a6.GGBS.ANH, a7.W/B.GGBS.ANH: Interaction effects of factors W/B, GGBS and ANH

$\varepsilon:$ Random error term representing the effects of uncontrolled variables

Analysis of variance (ANOVA) was used to test the significance of regression models, and ttests were performed to identify the non-significant (NS) variables and second order interactions, which were subsequently eliminated from the derived models. Model coefficients were determined using multi-linear regression analysis based on a normal distribution assumption. The error was assumed to be random and normally distributed, so the residual terms, which represent the difference between the actual and predicted values should exhibit similar properties [37]. The probability value (Prob.) obtained from ANOVA determines the statistical significance of each factor and their interactions. For most of the parameters, the probability that the derived coefficients associated with the various variables influencing each response were limited to $10 \%$. This signifies that there is less than $10 \%$ chance or $90 \%$ confidence limit that the contribution of a given parameter to the tested response exceeds the value of the specified coefficient. A negative estimate indicates that an increase of the given parameter results in a reduction of the measured response. 


\section{Results and discussion}

320 The results of the experimental work characterize the behaviour of the mortars with different $321 \mathrm{~W} / \mathrm{B}$, ANH and GGBS levels. Table 3 summarises all results of the experimental work 322 performed. The results were used to construct the regression models.

Table 3. Average results from experimental work

\begin{tabular}{ccccccccc}
\hline & \multicolumn{9}{c}{ Viscometer } & \multicolumn{3}{c}{ Induced bleeding } \\
\hline Mix & $\begin{array}{c}\text { Mini- } \\
\text { slump } \\
(\mathbf{m m})\end{array}$ & $\begin{array}{c}\text { Flow } \\
\text { time } \\
(\mathbf{s})\end{array}$ & $\begin{array}{c}\text { Cohesion } \\
\text { meter } \\
(\mathbf{m m})\end{array}$ & $\begin{array}{c}\text { Yield } \\
\text { value } \\
(\text { Pa) }\end{array}$ & $\begin{array}{c}\text { Plastic } \\
\text { viscosity } \\
(\mathbf{P a . s})\end{array}$ & $\mathbf{1 m i n}$ & $\mathbf{5 m i n}$ & $\mathbf{3 0 m i n}$ \\
& 61 & 230 & 10.5 & 19.1 & 0.923 & 22.0 & 47.0 & 48.0 \\
$\mathbf{1}$ & 89 & 25 & 5.5 & 9.7 & 0.323 & 29.0 & 78.0 & 81.0 \\
$\mathbf{2}$ & 67 & 200 & 11.8 & 17.2 & 0.802 & 28.0 & 58.0 & 60.5 \\
$\mathbf{3}$ & 111 & 12 & 2.0 & 8.0 & 0.199 & 49.0 & 86.0 & 86.0 \\
$\mathbf{4}$ & 52 & 360 & 14.3 & 25.1 & 1.203 & 28.0 & 52.0 & 54.0 \\
$\mathbf{5}$ & 83 & 69 & 8.6 & 9.9 & 0.403 & 36.0 & 70.0 & 70.0 \\
$\mathbf{6}$ & 60 & 250 & 12.5 & 21.1 & 0.980 & 31.0 & 58.0 & 59.0 \\
$\mathbf{7}$ & 110 & 13 & 4.0 & 7.7 & 0.224 & 35.0 & 91.0 & 95.0 \\
$\mathbf{8}$ & 71 & 150 & 8.7 & 10.1 & 0.617 & 37.0 & 72.0 & 73.0 \\
$\mathbf{9}$ & 73 & 102 & 12.2 & 10.6 & 0.681 & 29.0 & 62.0 & 62.0 \\
$\mathbf{1 0}$ & 77 & 192 & 8.9 & 12.4 & 0.660 & 29.0 & 64.0 & 64.5 \\
$\mathbf{1 1}$ & 74 & 83 & 11.0 & 10.1 & 0.641 & 35.0 & 71.5 & 72.0 \\
$\mathbf{1 2}$ & & & & & & & &
\end{tabular}

325

326

Table 3. Average results from experimental work (continued)

\begin{tabular}{|c|c|c|c|c|c|c|c|}
\hline \multirow[t]{2}{*}{ Mix } & \multirow{2}{*}{$\begin{array}{l}\text { Permeability } \\
\underset{(\mathrm{m} / \mathrm{s})}{\min }\end{array}$} & \multirow{2}{*}{$\begin{array}{l}\text { Permeability } \\
30 \mathrm{~min} \\
(\mathrm{~m} / \mathrm{s})\end{array}$} & \multirow{2}{*}{$\begin{array}{l}\text { Compre- } \\
\text { ssibility }\end{array}$} & \multicolumn{4}{|c|}{ Compressive strength } \\
\hline & & & & $\begin{array}{l}\mathbf{f}^{\prime} \mathbf{c} 1 d \\
\text { (MPa) }\end{array}$ & $\begin{array}{l}\mathbf{f}^{\prime} \mathbf{c} 3 d \\
(\mathbf{M P a})\end{array}$ & $\begin{array}{l}\mathbf{f}^{\prime} \mathbf{c} 7 d \\
(\mathbf{M P a})\end{array}$ & $\begin{array}{l}\mathbf{f}^{\prime} \mathbf{c} 28 d \\
(\mathbf{M P a})\end{array}$ \\
\hline 1 & $2.16 \mathrm{E}-09$ & $3.17 \mathrm{E}-09$ & 0.155 & 29.9 & 50.6 & 58.1 & 70.4 \\
\hline 2 & $5.12 \mathrm{E}-08$ & 4.18E-09 & 0.298 & 16.8 & 38.3 & 54.7 & 55.8 \\
\hline 3 & 4.48E-08 & $3.66 \mathrm{E}-09$ & 0.194 & 21.3 & 33.4 & 40.6 & 52.7 \\
\hline 4 & 3.74E-08 & $4.25 \mathrm{E}-09$ & 0.312 & 14.0 & 22.3 & 25.6 & 40.8 \\
\hline 5 & 4.48E-08 & $3.42 \mathrm{E}-09$ & 0.173 & 23.3 & 43.4 & 50.7 & 53.5 \\
\hline 6 & $5.12 \mathrm{E}-08$ & 3.95E-09 & 0.255 & 13.6 & 37.1 & 37.1 & 44.8 \\
\hline 7 & 4.40E-08 & 3.61E-09 & 0.187 & 10.8 & 23.2 & 34.3 & 53.2 \\
\hline 8 & $4.51 \mathrm{E}-08$ & 4.33E-09 & 0.342 & 6.8 & 20.0 & 26.3 & 47.3 \\
\hline 9 & 4.46E-08 & 4.02E-09 & 0.250 & 19.6 & 32.8 & 39.8 & 59.2 \\
\hline 10 & 4.68E-08 & 3.71E-09 & 0.212 & 17.1 & 23.2 & 36.1 & 55.6 \\
\hline 11 & $4.23 \mathrm{E}-08$ & 3.79E-09 & 0.221 & 20.7 & 31.3 & 45.1 & 56.5 \\
\hline 12 & $5.16 \mathrm{E}-08$ & $4.00 \mathrm{E}-09$ & 0.246 & 18.3 & 30.1 & 43.5 & 52.0 \\
\hline
\end{tabular}

328 The derived quadratic statistical models of grout for mini-slump, flow time, cohesion plate, yield stress, plastic viscosity, induced bleeding at $1 \mathrm{~min}, 5 \mathrm{~min}$ and $30 \mathrm{~min}$, permeability at 1 
min and 30 min, compressibility, and compressive strength at 1, 3, 7 and 28 days are given in Equations (4) to (18) where W/B, GGBS, and ANH are given in codes values.

Mini-Slump $(\mathrm{mm})=78.81+19.19 \mathrm{~W} / \mathrm{B}+7.81 \mathrm{ANH}+4.44 \mathrm{~W} / \mathrm{B} . \mathrm{ANH}-2.94$ GGBS

Marsh flow time $(\mathrm{s})=140.4-115.3 \mathrm{~W} / \mathrm{B}-26.1 \mathrm{ANH}+28.1 \mathrm{GGBS}$

Plate Cohesion meter $(\mu \mathrm{m})=8.6-3.66 \mathrm{~W} / \mathrm{B}+1.22 \mathrm{GGBS}-1.07 \mathrm{ANH}-0.91 \mathrm{~W} / \mathrm{B} . \mathrm{ANH}(6)$

Yield Value $(\mathrm{Pa})=14.66-5.84 \mathrm{~W} / \mathrm{B}-1.26 \mathrm{~W} / \mathrm{B} . \mathrm{GGBS}-1.25 \mathrm{ANH}+1.24 \mathrm{GGBS}$

Plastic Viscosity $($ Pa.s $)=0.63-0.34 \mathrm{~W} / \mathrm{B}-0.078 \mathrm{ANH}+0.073$ GGBS - 0.047 W/B.GGBS - 0.022 ANH.GGBS

Induced Bleeding at $1 \mathrm{~min}(\mathrm{ml})=32.25+5.0 \mathrm{~W} / \mathrm{B}+3.5 \mathrm{ANH}-2.25 \mathrm{~W} / \mathrm{B}$.ANH.GGBS

Induced Bleeding at 5 mins $(\mathrm{ml})=67.5+13.75 \mathrm{~W} / \mathrm{B}+5.75 \mathrm{ANH}$

Induced Bleeding at $30 \mathrm{mins}(\mathrm{ml})=69.19+13.81 \mathrm{~W} / \mathrm{B}+5.94 \mathrm{ANH}$

Permeability at $1 \mathrm{~min}(\mathrm{~m} / \mathrm{s}) \times 10^{-8}=4+0.615 \mathrm{~W} / \mathrm{B}+0.621 \mathrm{AHN}-0.773 \mathrm{~W} / \mathrm{B}$.GGBS

$$
\text { - 0.426W/B.AHN - 0.446 AHN.GGBS }
$$

Permeability at $30 \mathrm{~min}(\mathrm{~m} / \mathrm{s}) \times 10^{-8}=0.382+0.035 \mathrm{~W} / \mathrm{B}+0.014 \mathrm{ANH}$

$$
+0.008 \text { W/B.ANH.GGBS }
$$

Compressibility $=0.2396+0.0623 \mathrm{~W} / \mathrm{B}+0.0194 \mathrm{ANH}+0.0012 \mathrm{~W} / \mathrm{B} . \mathrm{ANH} . \mathrm{GGBS}$

$$
f_{\mathrm{c} 1 \mathrm{~d}}^{\prime}(\mathrm{MPa})=17.05-4.26 \mathrm{~W} / \mathrm{B}-3.84 \mathrm{ANH}-3.43 \mathrm{GGBS}+1.45 \mathrm{~W} / \mathrm{B} . \mathrm{ANH}
$$

$$
f^{\prime}{ }_{\mathrm{c} 3 \mathrm{~d}}(\mathrm{MPa})=32.15-8.79 \mathrm{ANH}-4.12 \mathrm{~W} / \mathrm{B}-2.61 \mathrm{GGBS}
$$

$f_{\mathrm{c} 7 \mathrm{~d}}^{\prime}(\mathrm{MPa})=40.92-9.24 \mathrm{ANH}-5 \mathrm{~W} / \mathrm{B}-3.83$ GGBS 
The correlation coefficient of most of the proposed models were higher than 0.90 except for plastic viscosity, compressive strength after 3days and compressive strength after 28days, which have coefficients of $0.70,0.86$ and 0.87 , respectively.

Table 4 shows the average measured responses of the four replicate grouts, the coefficients of variation (COV), as well as the estimated errors with a $90 \%$ confidence limit for each of the measured properties. The estimated error levels for mini-slump, plate cohesion meter, Marsh cone, yield stress, plastic viscosity, induced bleeding at $1 \mathrm{~min}, 5 \mathrm{~min}$ and $30 \mathrm{mins}$, permeability at $1 \mathrm{~min}$ and $30 \mathrm{~min}$, compressibility, and compressive strengths at 1, 3, 7, 28 days were \pm 2.2 $\mathrm{mm}, \pm 0.001 \mathrm{~mm}, \pm 40 \mathrm{~s}, \pm 0.9 \mathrm{~Pa}, \pm 0.02 \mathrm{~Pa} \mathrm{~s}, \pm 2.8 \mathrm{ml}, \pm 4.2 \mathrm{ml}, \pm 4.5 \mathrm{ml}, \pm 3.2 \times 10^{-9}(\mathrm{~m} / \mathrm{s})$, $\pm 1.3 \times 10^{-10}(\mathrm{~m} / \mathrm{s}), \pm 0.0153, \pm 1.3 \mathrm{MPa}, \pm 3.5 \mathrm{MPa}, \pm 3.3 \mathrm{MPa}$ and $\pm 2.5 \mathrm{MPa}$, respectively. The relative experimental errors for mini-slump, plate cohesion meter, Marsh cone, yiled stress, plastic viscosity, induced bleeding, permeability, compressibility, compressive strengths were limited to $3-11 \%$. On the other hand, relative error for march cone was up to $30 \%$.

Table 4. Repeatability of test parameters at the central point

\begin{tabular}{ccccccccc}
\hline Tests & $\begin{array}{c}\text { Mini- } \\
\text { slump }\end{array}$ & $\begin{array}{c}\text { Plate } \\
\text { cohesion }\end{array}$ & $\begin{array}{c}\text { Marsh } \\
\text { cone }\end{array}$ & $\begin{array}{c}\text { Yield } \\
\text { stress }\end{array}$ & $\begin{array}{c}\text { Plastic } \\
\text { viscosit } \\
\mathbf{y}\end{array}$ & $\begin{array}{c}\text { Induced } \\
\text { bleeding } \\
\text { at 1 min }\end{array}$ & $\begin{array}{c}\text { Induced } \\
\text { bleedin } \\
\text { g at 5 } \\
\text { min }\end{array}$ & $\begin{array}{c}\text { Induced } \\
\text { bleeding } \\
\text { at 30 } \\
\text { min }\end{array}$ \\
\hline $\begin{array}{c}\text { Mean (n=4) } \\
\text { Coefficient }\end{array}$ & $\begin{array}{c}73.6 \\
\mathrm{~mm}\end{array}$ & $\begin{array}{c}0.01 \\
\mathrm{~mm}\end{array}$ & $\begin{array}{c}131.8 \\
\mathrm{~s}\end{array}$ & $\begin{array}{c}10.8 \\
\mathrm{~Pa}\end{array}$ & $\begin{array}{c}0.65 \\
\mathrm{~Pa} \mathrm{~s}\end{array}$ & $\begin{array}{c}32.5 \\
\mathrm{ml}\end{array}$ & $\begin{array}{c}67.4 \\
\mathrm{ml}\end{array}$ & $\begin{array}{c}67.9 \\
\mathrm{ml}\end{array}$ \\
$\begin{array}{c}\text { of variation } \\
(\%)\end{array}$ & 3.7 & 11.5 & 37.2 & 10.5 & 4.2 & 12.7 & 7.6 & 8.0 \\
$\begin{array}{c}\text { Estimate } \\
\text { error (90\% } \\
\text { confidence } \\
\text { limit) }\end{array}$ & $\mathrm{mm}$ & $\mathrm{mm}$ & $\mathrm{s}$ & $\mathrm{Pa}$ & $\mathrm{Pa} \mathrm{s}$ & $\mathrm{ml}$ & $\mathrm{ml}$ & $\mathrm{ml}$ \\
\hline
\end{tabular}

Table 4. Repeatability of test parameters at the central point (continued)

\begin{tabular}{|c|c|c|c|c|c|c|c|}
\hline Tests & $\begin{array}{c}\text { Permeability } \\
1 \text { min } \\
\text { x10 }^{-8} \\
\end{array}$ & $\begin{array}{c}\text { Permeability } \\
30 \mathrm{~min} \\
\mathbf{x 1 0}^{-8} \\
\end{array}$ & Compressibility & $f^{\prime} c_{1 \mathrm{~d}}$ & $f_{c}^{\prime} 3 \mathrm{~d}$ & $f^{\prime}{ }^{\prime} 7 \mathrm{~d}$ & $f^{\prime} c_{28 d}$ \\
\hline Mean $(n=4)$ & $\begin{array}{c}4.63 \\
\mathrm{~m} / \mathrm{s}\end{array}$ & $\begin{array}{c}0.388 \\
\mathrm{~m} / \mathrm{s}\end{array}$ & 0.2323 & $\begin{array}{l}18.9 \\
\mathrm{MPa}\end{array}$ & $\begin{array}{l}29.3 \\
\mathrm{MPa}\end{array}$ & $\begin{array}{l}41.1 \\
\mathrm{MPa}\end{array}$ & $\begin{array}{l}55.8 \\
\mathrm{MPa}\end{array}$ \\
\hline $\begin{array}{c}\text { Coefficient } \\
\text { of variation } \\
(\%)\end{array}$ & 8.5 & 3.9 & 8 & 8.4 & 14.4 & 9.8 & 5.3 \\
\hline
\end{tabular}


Estimate

\begin{tabular}{lccccccc} 
error $(90 \%$ & 0.32 & 0.013 & 0.0153 & 1.3 & 3.5 & 3.3 & 2.4 \\
$\begin{array}{c}\text { confidence } \\
\text { limit })\end{array}$ & $(\mathrm{m} / \mathrm{s})$ & $(\mathrm{m} / \mathrm{s})$ & & $\mathrm{MPa}$ & $\mathrm{MPa}$ & $\mathrm{MPa}$ & $\mathrm{MPa}$ \\
\hline
\end{tabular}

\subsection{Accuracy of the established models}

The ratio of predicted-to-measured properties for grout ranged between 0.87 and 1.15, indicating good accuracy for prediction of mini-slump, plate cohesion, induced bleeding at 1 min, 5 mins and 30 mins, yield stress, plastic viscosity and compressive strength at 1-d, 3-d, 7$\mathrm{d}$ and 28-d. In general, the proposed models for mini-slump, plate cohesion, Marsh cone, and compressive strength appeared to be accurate in predicting fluidity, cohesivity, induced bleeding, permeability at $30 \mathrm{~min}$, compressibility, and compressive strength, with low scatter between measured and predicted values. However, the average values of predicted/measured ratio of yield values were slightly higher (0.74).

\subsection{Isoresponses of the proposed models}

The isoresponse surfaces and contour plots for mini-slump, plate cohesion, Marsh cone, yield stress plastic viscosity, induced bleeding at $1 \mathrm{~min}, 5 \mathrm{mins}$ and $30 \mathrm{mins}$, permeability at $1 \mathrm{~min}$ and 30 mins, compressibility, and compressive strength at 1-d, 3-d, 7-d and 28-d were obtained by using response surface methodology (RSM). The isoresponse surfaces and contour plots were obtained from the regression models, and because the models contained interaction and second-order variables, the contour lines were curved.

The proposed statistical models can therefore be used to evaluate the effect of a group of variables on the properties affecting the quality of supersulfated grout. This allowed for the calculation of isoresponse surfaces from the parameters under study outside the experimental domain and the optimisation of their effects. The next sections will discuss the results of each experiment separately.

\subsubsection{Mini-slump}

As shown in Eq. 4, the mini-slump is influenced in order of significance by W/B ratio, anhydrite proportion, interaction of $\mathrm{W} / \mathrm{B}$ and $\mathrm{ANH}$, and the percentage of GGBS content. The W/B ratio had the greatest effect on fluidity due to better lubrication of the particles in the paste 
[29]. The mini-slump test was accompanied by very low shear. The value of mini-slump is to characterise yield stress [38], therefore higher mini-slump value indicated a lower yield stress.

416 The effect of W/B on the increase of mini-slump was two and half-time than that of ANH (19.2 vs. 7.81 in Eq. 4). However, increased ANH resulted in a 2.7 times greater increase in mini418 slump than reduced GGBS (7.81 vs. -2.94 in Eq. 4). Figure 1(a) shows the effect of increased 419 W/B on mini-slump vs. ANH (when GGBS was kept constant at 70\%), and Figure 1(b) shows 420 GGBS vs. ANH (when W/B was fixed at 0.39). Based on these figures, it is evident that mini421 slump increased significantly when the dosage of W/B and ANH increased.

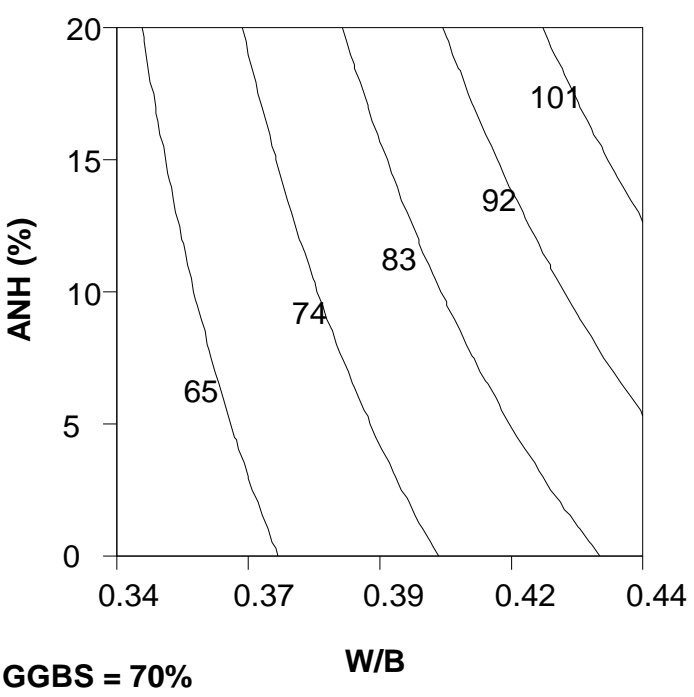

(a)

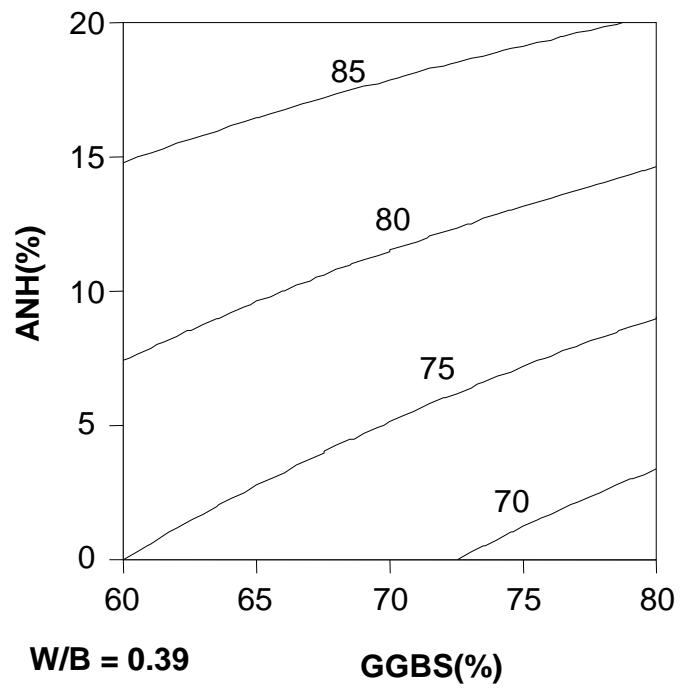

(b)

Fig. 1. Isoresponse curves of mini-slump (mm): (a) W/B vs. ANH, and (b) GGBS vs. ANH

\subsubsection{Marsh cone}

427 The time needed for a grout sample to flow through the Marsh cone is proportional to the 428 viscosity of the cement grout; the flow time becomes an index of fluidity, so the longer the 429 flow time, the lower the fluidity. Similar to the previous trends, Eq. 5 shows that the values of 430 Marsh cone are influenced in order of significance by W/B, GGBS and ANH. This is graphically illustrated in Figure 2. 
432

433

434

435

436

437

438

439

440

441

442

443

444

445

446

447

448

449

450

451

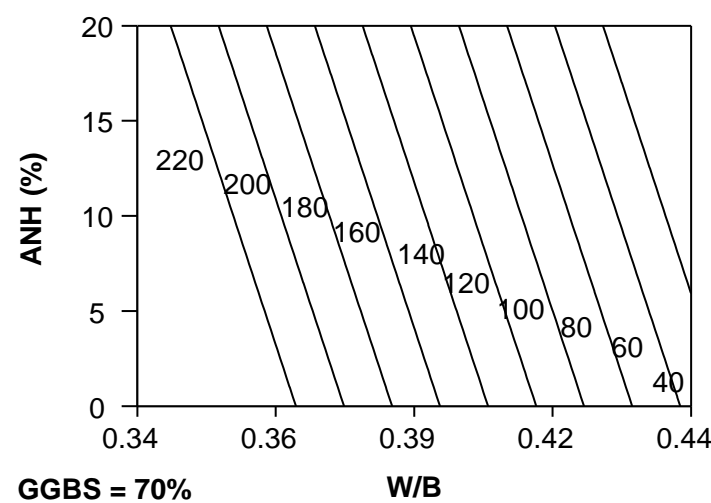

(a)

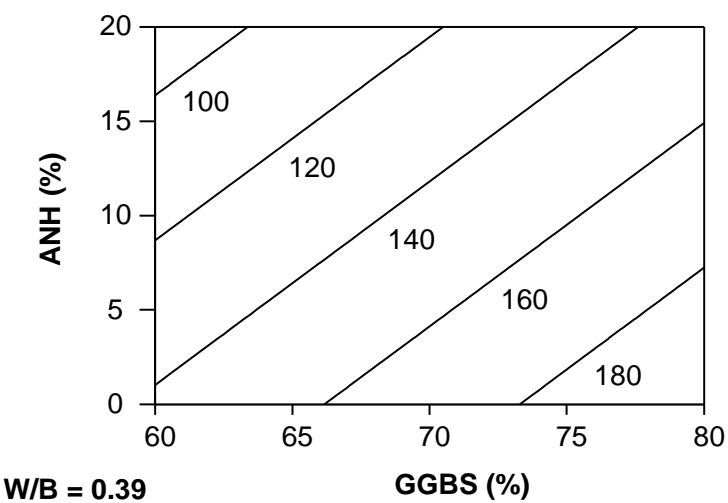

(b)

Fig. 2. Isoresponse curves for flow time (s): (a) W/B vs. ANH and (b) GGBS vs. ANH

It can be noted that an increase in W/B and ANH, or a reduction in GGBS, led to decreasing the Marsh cone flow time. For example, at fixed W/B at 0.39 and GGBS of 70\%, respectively, the increase in ANH dosage from 5 to $20 \%$ led to a marked reduction of the Marsh cone flow time from 170 to $140 \mathrm{~s}$ (Figure 2(a)). This behaviour is attributed to the change in plastic viscosity of the grout as will be discussed later.

\subsubsection{Cohesion plate}

As shown in Eq. 6, the cohesion plate was influenced, in order of magnitude, by the W/B, and the percentage of GGBS and ANH. The increasing W/B had a 3.4 times the influence on the reduction of the cohesion plate test results as the increased ANH (for a GGBS constant). By comparing the effects of W/B and GGBS on plate cohesion, the increased W/B can be interpreted as having approximately a 3 times greater influence on the reduction of plate cohesion values than the increase in GGBS (-3.66 vs. 1.22 in Eq. 6), given that ANH is held constant. The effect of an increase in W/B from 0.34 to 0.44 and ANH from $0 \%$ to $20 \%$ with a fixed GGBS dosage of $70 \%$ is presented in Figure 3(a). Increased W/B led to a decreased cohesion plate value. Conversely, an increase in GGBS increased the cohesion plate value and an increased ANH caused a reduction in cohesion plate (Figure 3(b)). 
452

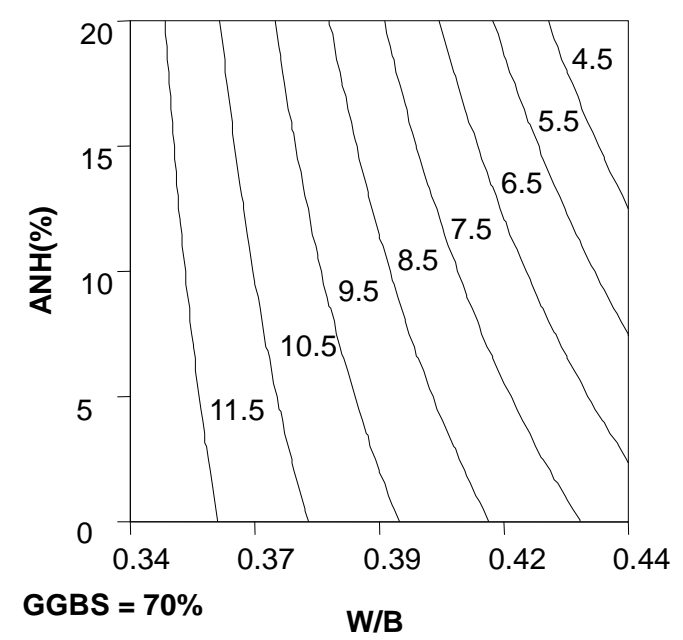

(a)

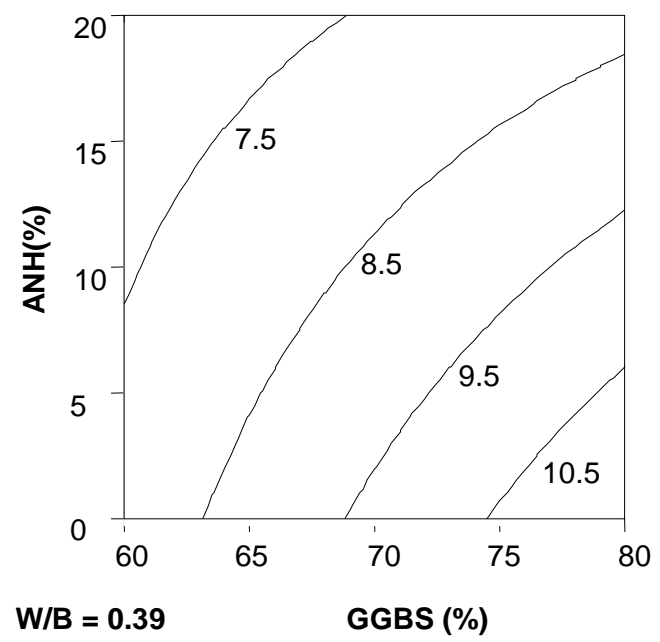

(b)

Fig. 3. Isoresponse curves for plate cohesion meter: (a) W/B vs. ANH, and (b) GGBS vs.

\subsubsection{Yield stress}

$\mathrm{ANH}$

As shown in Eq. 7, yield value was influenced, in order of magnitude, by W/B, and dosages of ANH and GGBS. Based on Figure 4 (a), when W/B was fixed at 0.39, GGBS maintained at $70 \%$, and ANH increased to 5\%, the isoresponse curve showed a yield value of $15 \mathrm{~Pa}$. On the other hand, if the proportion of ANH was further increased to $20 \%$ while GBBS was maintained at $70 \%$, the yield value decreased to $13.5 \mathrm{~Pa}$. This corresponds with Eq. (7), in which the proportion of W/B and ANH were increased, while GGBS was kept constant, resulting in a reduction in yield stress. An increase in GGBS content resulted in an increase of the yield stress.

Figure 4 (b) shows the isoresponse curve of the yield value with a fixed proportion of GGBS at $70 \%$. When W/B was 0.39 and $\mathrm{ANH}$ was $5 \%$, the isoresponse of the predicted yield value was $15.5 \mathrm{~Pa}$. If $\mathrm{ANH}$ was increased to $20 \%$ while maintaining $\mathrm{W} / \mathrm{B}$ at 0.39 , the isoresponse of the yield value was $13.5 \mathrm{~Pa}$.

It can be interesting to note that the observed results for the yield stress are closed to the one observed with the cohesion plate and mini-slump tests. This is expected as yield stress values can be derived from those two simple tests. 


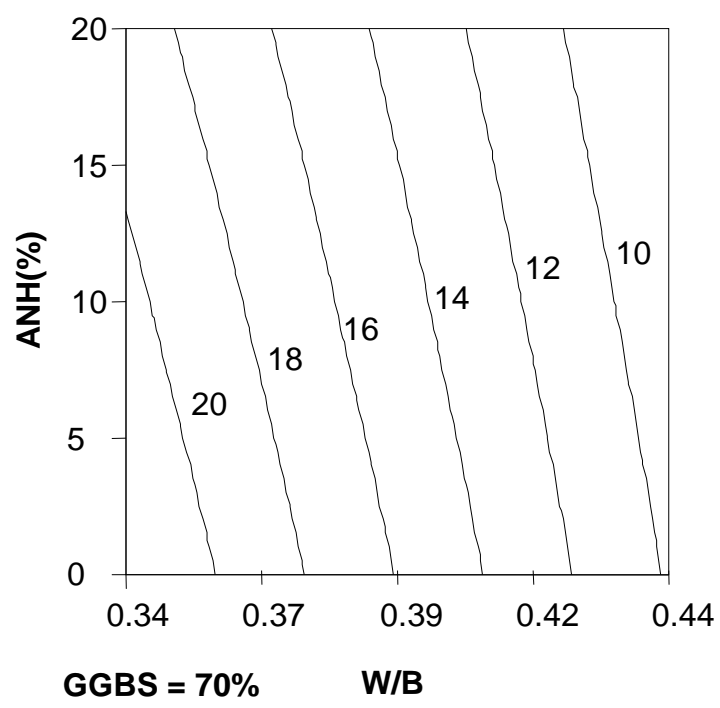

472

473

474

475

476 Plastic viscosity was influenced, in order of magnitude, by W/B, and the dosages of ANH and

477 GGBS. ANH and GGBS had almost opposite effects on plastic viscosity (-0.078 vs. 0.073 in

478 Eq. 8). As shown in Eq. (8), increased W/B had the greatest primary effect on plastic viscosity

479 (0.34 vs. 0.078 and 0.073$)$. The increased W/B had approximately a 4.4 times greater influence 480 on reducing plastic viscosity than increased ANH or decreased GGBS.

481 In the isoresponse curve of plastic viscosity shown in Figure 5 (a), when GGBS was fixed at $48270 \%, \mathrm{~W} / \mathrm{B}$ set at 0.39 , and $\mathrm{ANH}$ maintained at $5 \%$, the predicted plastic viscosity value was 483 0.68 Pa.s. On the other hand, if the dosage of ANHB was increased to 20\% while maintaining 484 a similar W/B, the plastic viscosity was reduced to 0.55 Pa.s.

485 In Figure 5 (b), W/B was fixed at 0.39, when GGBS was held at 70\% and ANH at 5\%, the 486 predicted plastic viscosity was 0.67 Pa.s. However, when ANH was increased to $20 \%$ and 487 GGBS was maintained at 70\%, the predicted plastic viscosity dropped to 0.55 Pa.s. 


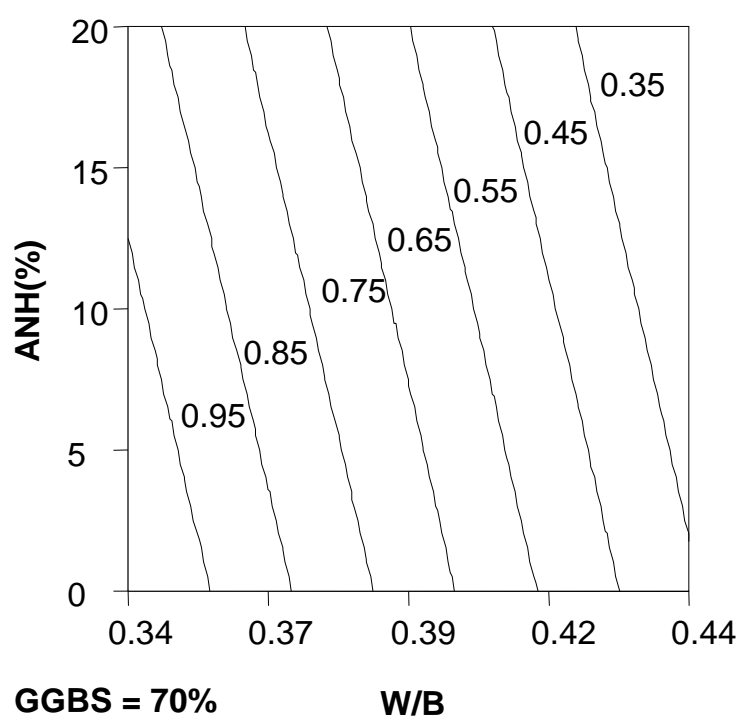

(a)

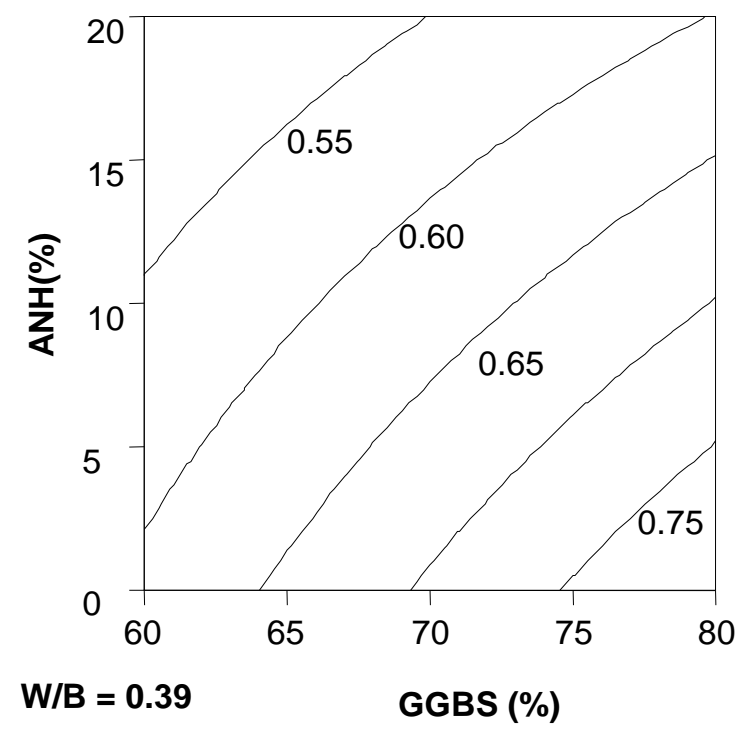

(b)
489

490

491

492

493

494

495

496

497

498

499

Fig. 5. Isoresponse curve for plastic viscosity (Pa.s): (a) W/B vs. ANH, and (b) GGBS vs. ANH

\subsubsection{Induced bleeding}

The induced bleeding equations for 1 and 5 minutes (Eqs. 9, 10) and 30 minutes (Eq. 11) are very similar. The two influencing factors of induced bleeding are W/B ratio and anhydrite. W/B ratio has the greatest effect, over two times the effect of anhydrite content. Figure 6 shows the isoresponse for bleeding versus the W/B ratio for a fixed value of GGBS at 70\%. It can be seen that when an anhydrite value is selected and the W/B ratio is increased the bleeding will also increase. Similarly, if a W/B ratio is selected and the anhydrite content is increased the bleeding will again increase.

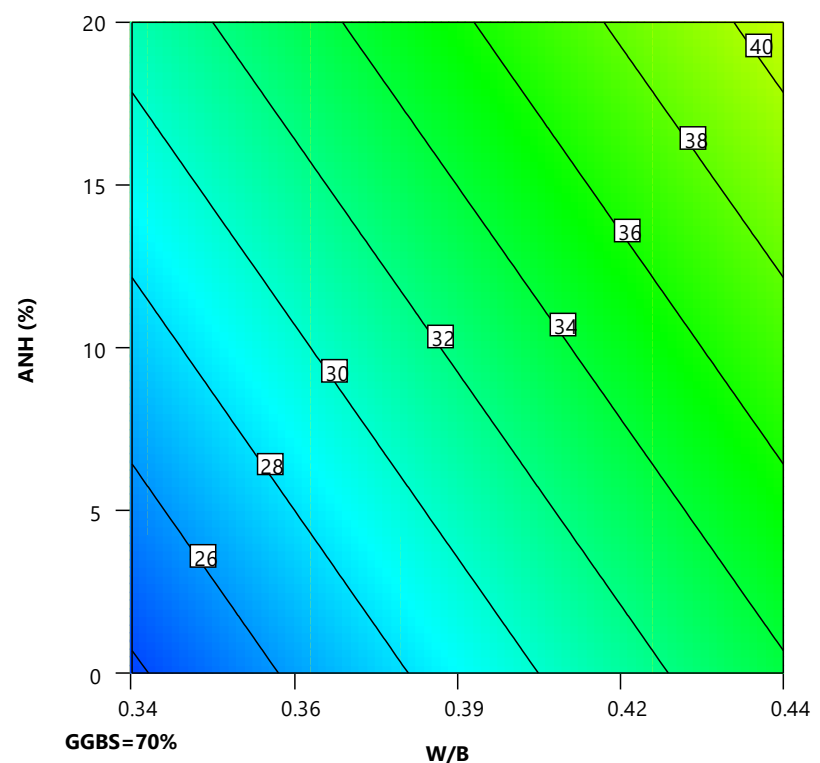




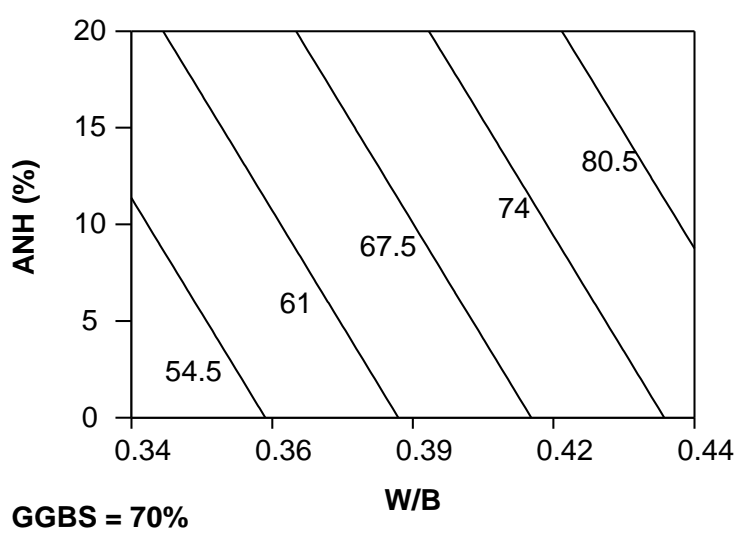

502

503

504

505

506

507

508

509

510

511 Similarly, the permeability at $30 \mathrm{~min}$ is affected in order of significance by W/B followed by

512 ANH (Eq. 13). In Figure 7 (b), W/B was fixed at 0.39, when GGBS was held at 70\% and ANH

513 at $10 \%$, the predicted permeability was $0.38 \times 10^{-8}(\mathrm{~m} / \mathrm{s})$. However, when ANH was increased

514 to $20 \%$ and GGBS was maintained at $70 \%$, the predicted permeability increased to $0.40 \times 10^{-8}$

$515(\mathrm{~m} / \mathrm{s})$. (c)

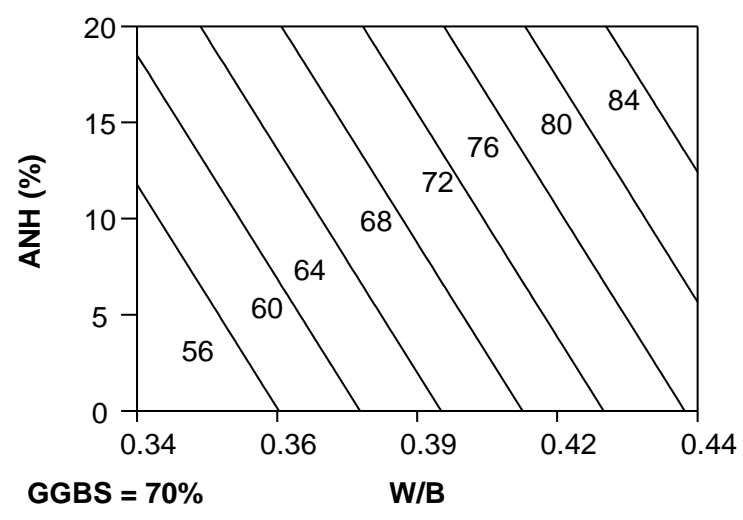

Fig. 6. Isoresponse curves for induced bleeding at 1, 5 and $30 \mathrm{~min}$ : W/B vs. ANH

\subsubsection{Permeability}

Figure 7 (a) and (b) showed firstly that the permeability decreased significantly from 1 min to $30 \mathrm{~min}$. Permeability at 1 min was influenced, in order of magnitude, by W/B, and the dosage of ANH. All interactions between 3 parameters had almost opposite effects on permeability (Eq. 12). As shown in Eq. (12), increased W/B and AHN had the greatest primary effect on permeability at $1 \mathrm{~min}$. It seems there is an optimum reached at $\mathrm{W} / \mathrm{B}=40$ and $\mathrm{AHN}$ at $17 \%$.

516 


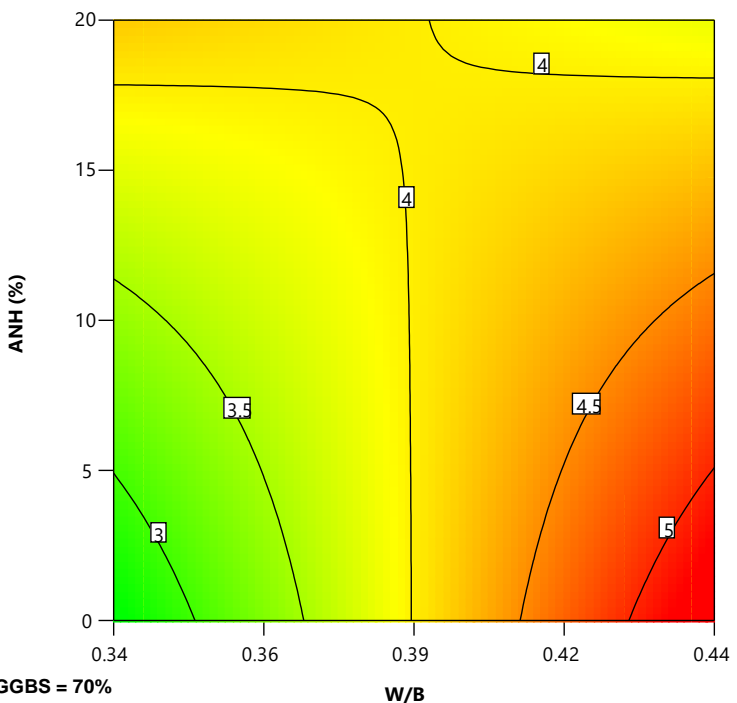

(a)

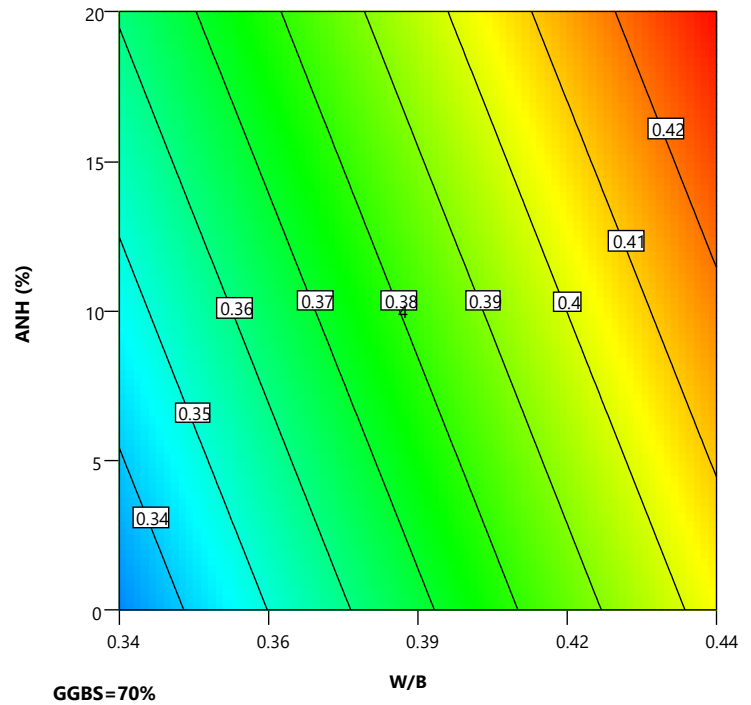

(b)

Fig. 7. Isoresponse curves for permeability at 1 and $30 \mathrm{~min}$ : W/B vs. ANH

520

521

522

523

524

525

526

527

\subsubsection{Compressibility}

As shown in Eq. (14), the compressibility was influenced, in order of magnitude, by the W/B, and the percentage of ANH. The interaction between 3 parameters affected also the compressibility. The increasing W/B had a 3.2 times the influence on the increase of the compressibility results as the increased ANH (for a GGBS constant). The effect of an increase in W/B from 0.34 to 0.44 and ANH from $0 \%$ to $20 \%$ with a fixed GGBS dosage of $70 \%$ is presented in Figure 8. Increased W/B led to an increase of compressibility. Similarly, an increase in AHN increased the compressibility.

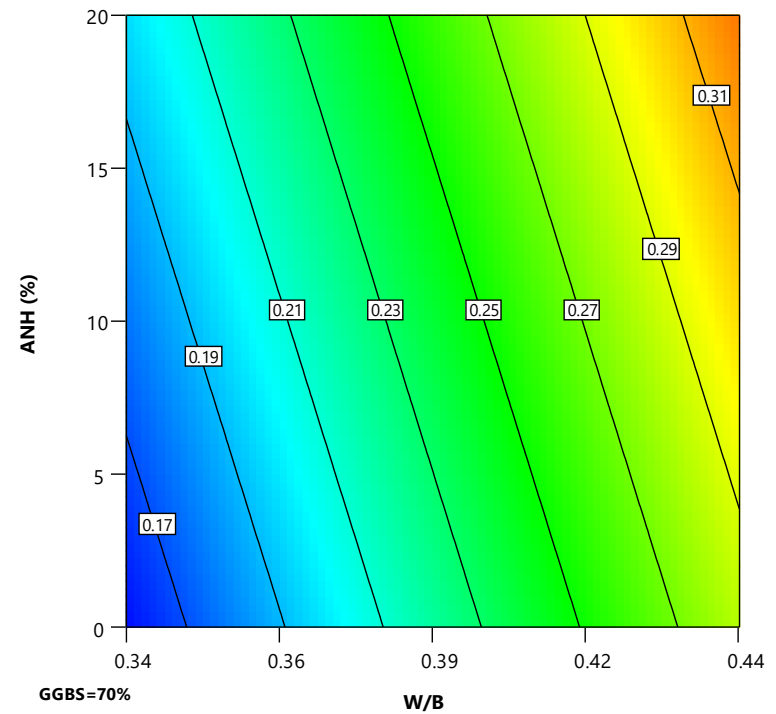

Fig. 8. Isoresponse curves for compressibility: W/B vs. ANH 


\subsubsection{Compressive strength}

532 After one day, from Eq. 15, the influencing factors, in order of significance, are W/B ratio, 533 anhydrite content, GGBS content and the interaction of W/B and ANH. The effect of the first 534 three was similar but W/B had 1.1 times greater effect than anhydrite and 1.25 times greater 535 effect than GGBS. While the interaction of W/B and anhydrite had around a third of the 536 influence of W/B. Figures 9 (a) and (b) show the isoresponses for 1-day compressive strength.

537 From Figure 9 (a) it can be seen when the GGBS content is fixed at 70\% for a given anhydrite 538 content, increasing the W/B ratio will decrease the strength. Also, if a W/B ratio is selected and 539 the anhydrite is increased similarly the strength will decrease. From Figure 9 (b) with the W/B 540 ratio fixed at 0.39 , once again an increase in GGBS led to a reduction of compressive strength 541 at 1 day.

542

543

544 545

546

547

548

549

550

551

552

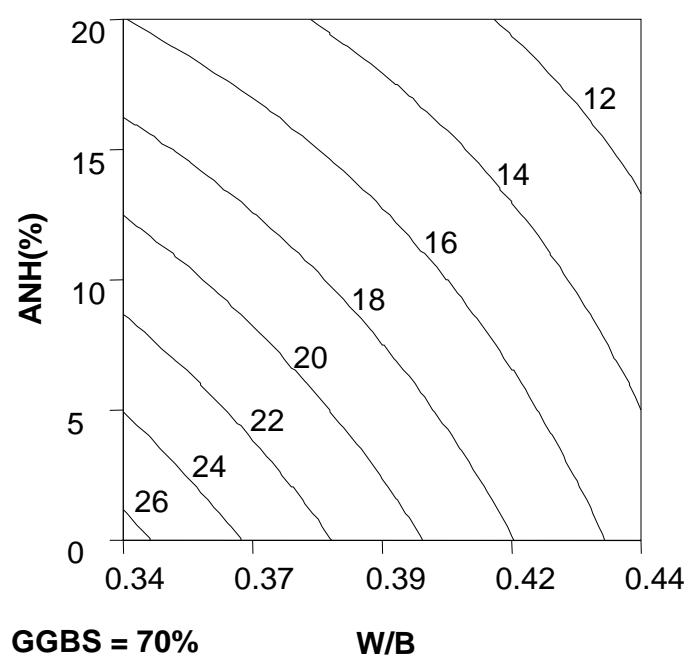

(a)

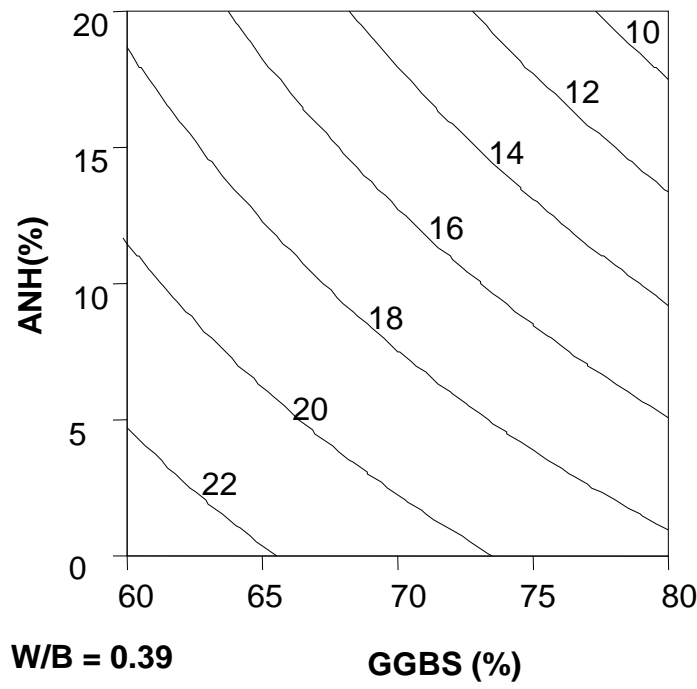

(b)

Fig.9. Isoresponse curves for compressive strength at 1d: (a) (W/B vs. ANH), and (b) (GGBS vs. ANH).

Eqs. 16, 17 and 18 show the effect of GGBS and ANH percentages on compressive strength at 3-d, 7-d and 28-d. Figures 10, 11, and 12 show the isoresponse of the compressive strength at 3-d, 7-d and 28-d, respectively, with W/B vs, ANH. Increased ANH led to a decrease of 3-d and 7-d compressive strength. As expected, an Increase in W/B led to a decrease in compressive strength. The percentage of ANH had a negative effect on compressive strength and showed a greater influence particularly at 3-d and 7-d (8.79 (3 d) \& 9.24 (7d) vs. 3.82 (28 d)). GGBS has a negative impact on early strength development. The negative effect of GGBS on compressive 
553

554

555

556

557

558

559

560

561

562

563

564

565

566

567

strength at early ages is clearly attributable to the fact that up to $80 \%$ of cement has been replaced by GGBS, and it takes some time for GGBS to start developing its pozzolanic action at a noticeable level. The results indicate that ANH content influences strength to a greater extent than GGBS at all ages. The SO3 content was reported to have great influence on the strength $[39,40]$.
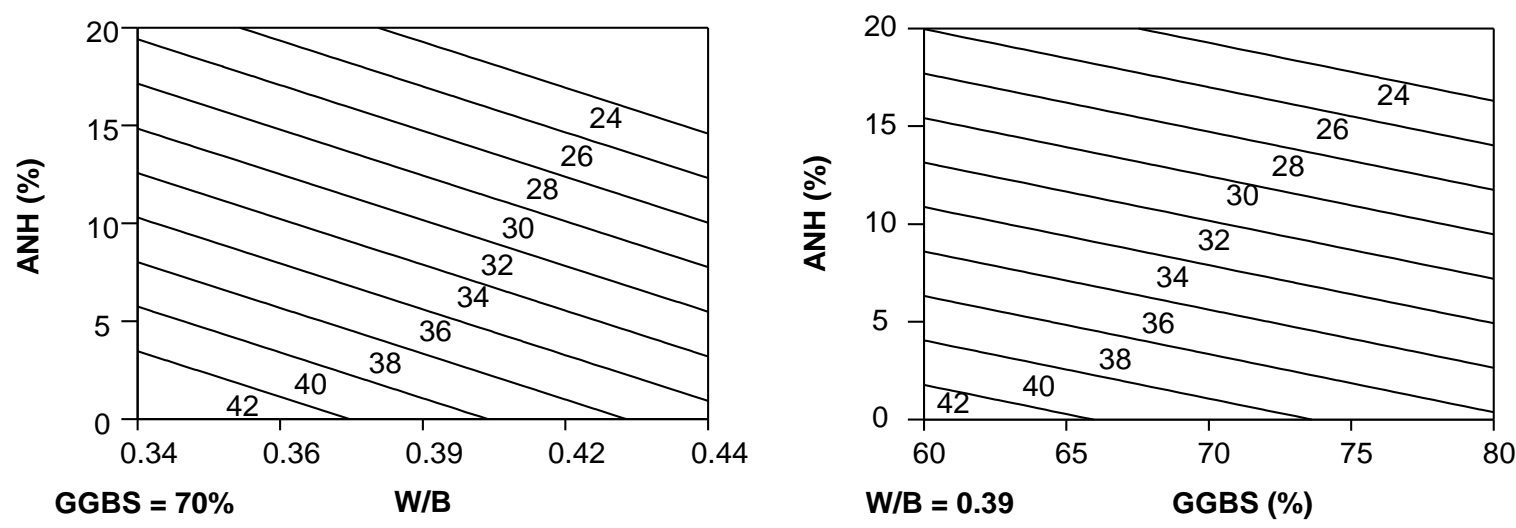

(a)

(b)

Fig.10. Isoresponse curves for compressive strength at 3d: (a) (W/B vs. ANH), and (b) (GGBS vs. ANH).

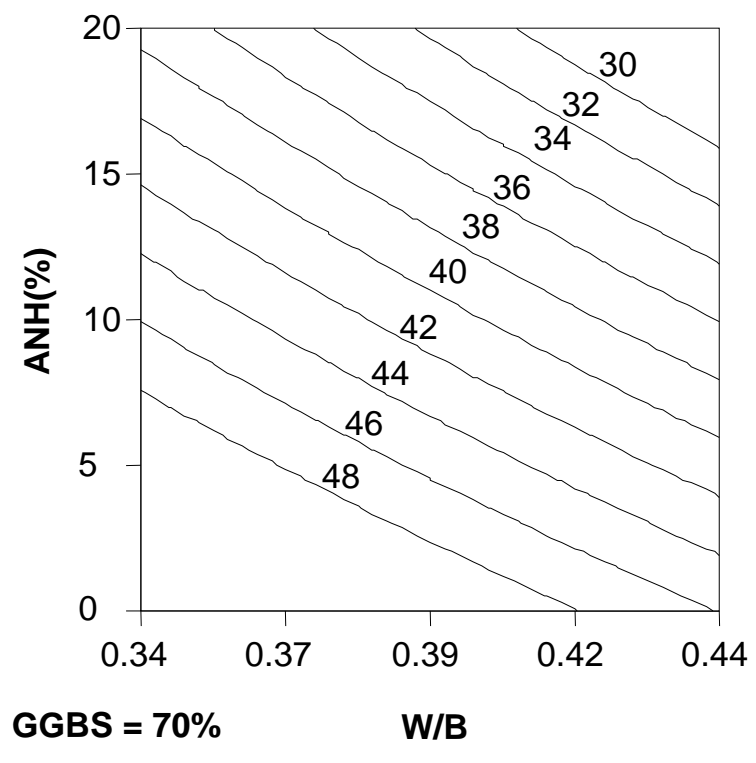

(a)

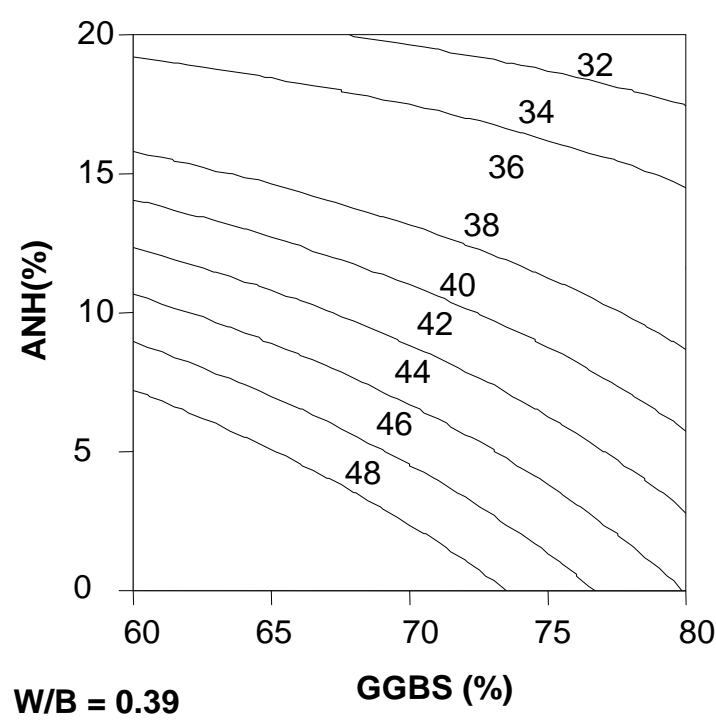

(b)

Fig.11. Isoresponse curves for compressive strength at 7d: (a) (W/B vs. ANH), and (b) (W/B vs. ANH). 
568

569

570

571

572

573

574

575

576

577

578

579

580

581

582

583

584

585

586

587

588

589

590

591

592

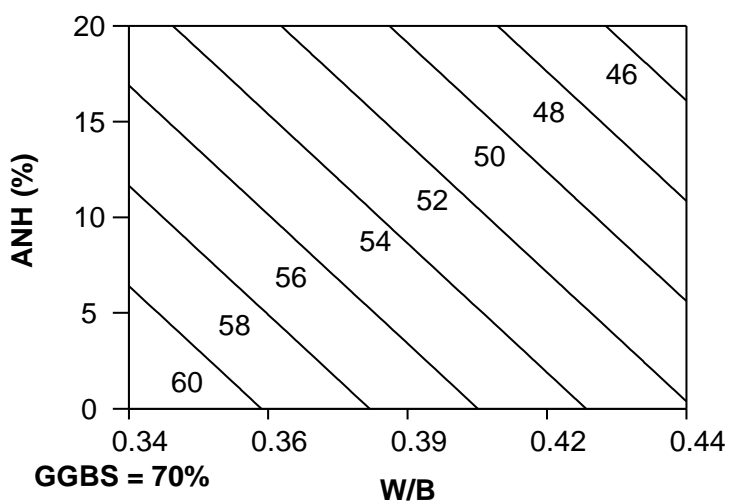

(a)

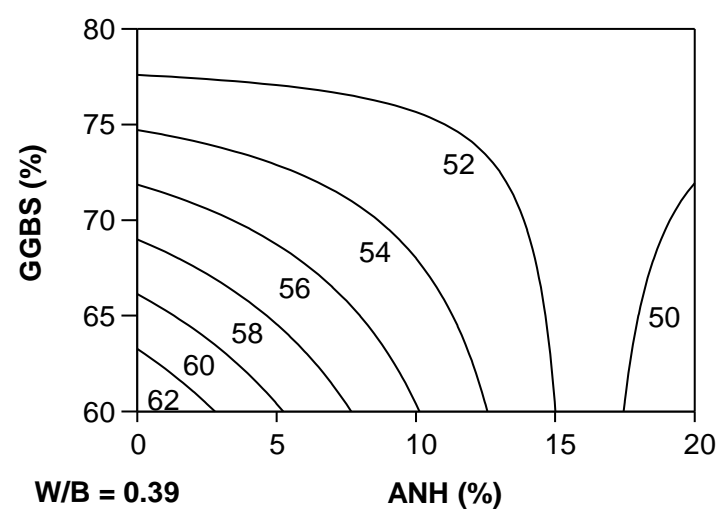

(b)

Fig.12. Isoresponse curves for compressive strength at 28d: (a) (W/B vs. ANH), and (b) (ANH vs. GGBS).

\subsubsection{Discussion of the effect of W/B, GGBS, and ANH}

As expected, the increase of W/B led to an increase in mini-slump, induced bleeding and a reduction in flow time, plate cohesion, yield stress, plastic viscosity and compressive strengths. This can be attributed to more water in the system.

An increase in GGBS content resulted in a reduction of the flow time, plate cohesion, yield stress and plastic viscosity while the fluidity is improved. This was due to the fact the specific gravity of slag is lower than that of PC leading to an increase in the paste volume and thus improving the fluidity of paste.

In case of an increase of ANH proportion, while W/B and GGBS were kept constant, it led to an increased mini-slump and induced bleeding, while the flow time, plate cohesion, yield stress, and plastic viscosity were reduced. This was due to the lower reactivity of ANH resulting in an increase of water needed for lubrication of paste.

As expected, an increase in W/B lead to an increase in induced bleeding, permeability and a decrease in compressibility $[33,35]$. This is due to the increase in liquid volume between the particles and to the reduction in the amount of interparticle forces. Globally, the compressibility decreases and the permeability increases with ANH. It can be explained by the reduced specific area and lower reactivity that can lead to more available water in the samples.

\subsubsection{Heat of Hydration}

Heat of hydration is considered an important factor in the cement design as low heat of hydration reduces the effect of thermal cracking. The heat flow results of the calorimeter test performed over a three days period can be seen in Figure 13. 


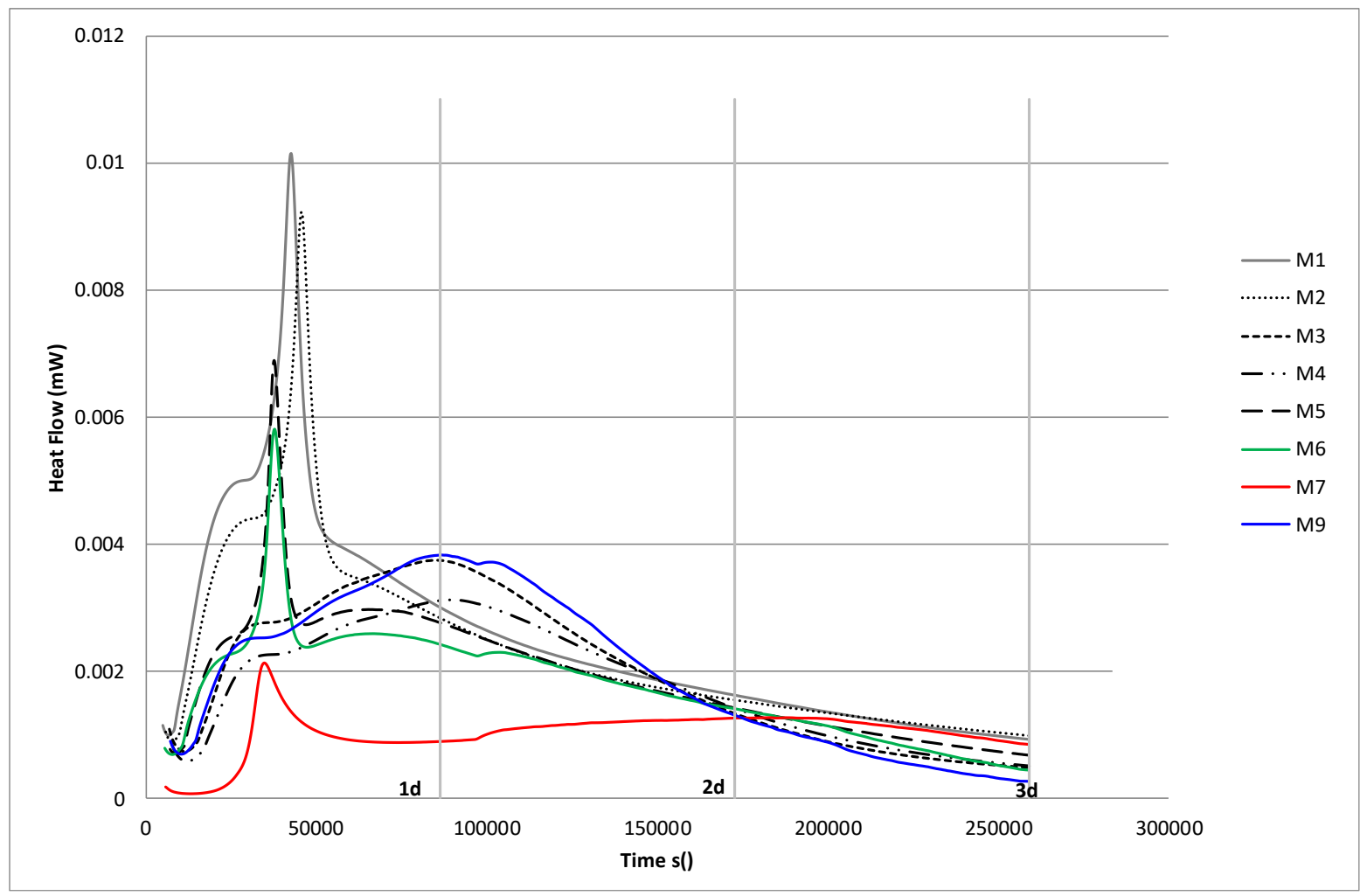

Fig. 13: Heat flow graphs for first 3 days of reaction.

595 Figure 13 presents that the largest peaks were in mixes 1, 2, 5 and 6. This shows that these reactions generated the most heat, and that they were quick. Mixes 1 and 2 have the highest OPC content at $40 \%$ and this suggests that to lower the heat of the reaction minimal OPC should be used. This is confirmed by the fact that mixes 5 and 6 have the next highest OPC contents, the same percentage as mixes 3,4 and 9 (one of the repeated mixes) which have anhydrite present. This implies that the presence of anhydrite will lengthen the reaction process and reduce the heat produced during setting significantly. The graph shows this by the absence of a sharp peak, instead a gentle curved hump is shown over a 2-day period whereas the mixes showing a sharp peak occur after about $12 \mathrm{hrs}$. Mix 7, which has the same solids content as mix 8 but a lower W/B ratio and no cement present, showed the lowest heat flow during the hydration process.

Figure 14 shows the cumulative heat generation during the first 3 days of setting. It is clear that the two mixes (1 and 2) with highest cement content and absence of anhydrite had the highest cumulative heat development over the 3-day period 643J and 594J, respectively. Mixes 3,4,5,6 and 9 which all have 20\% OPC content generated similar heat value over the 3 days. Results of mixes containing ANH implies that over the period that the anhydrite did not reduce the cumulative heat generated but slowed the reaction and reduce the peak heat generated. The 
graphs also suggest that a higher W/B ratio produced a lower cumulative and peak heat generation.

614

615

616

617

618

619

620

621

622

623

624

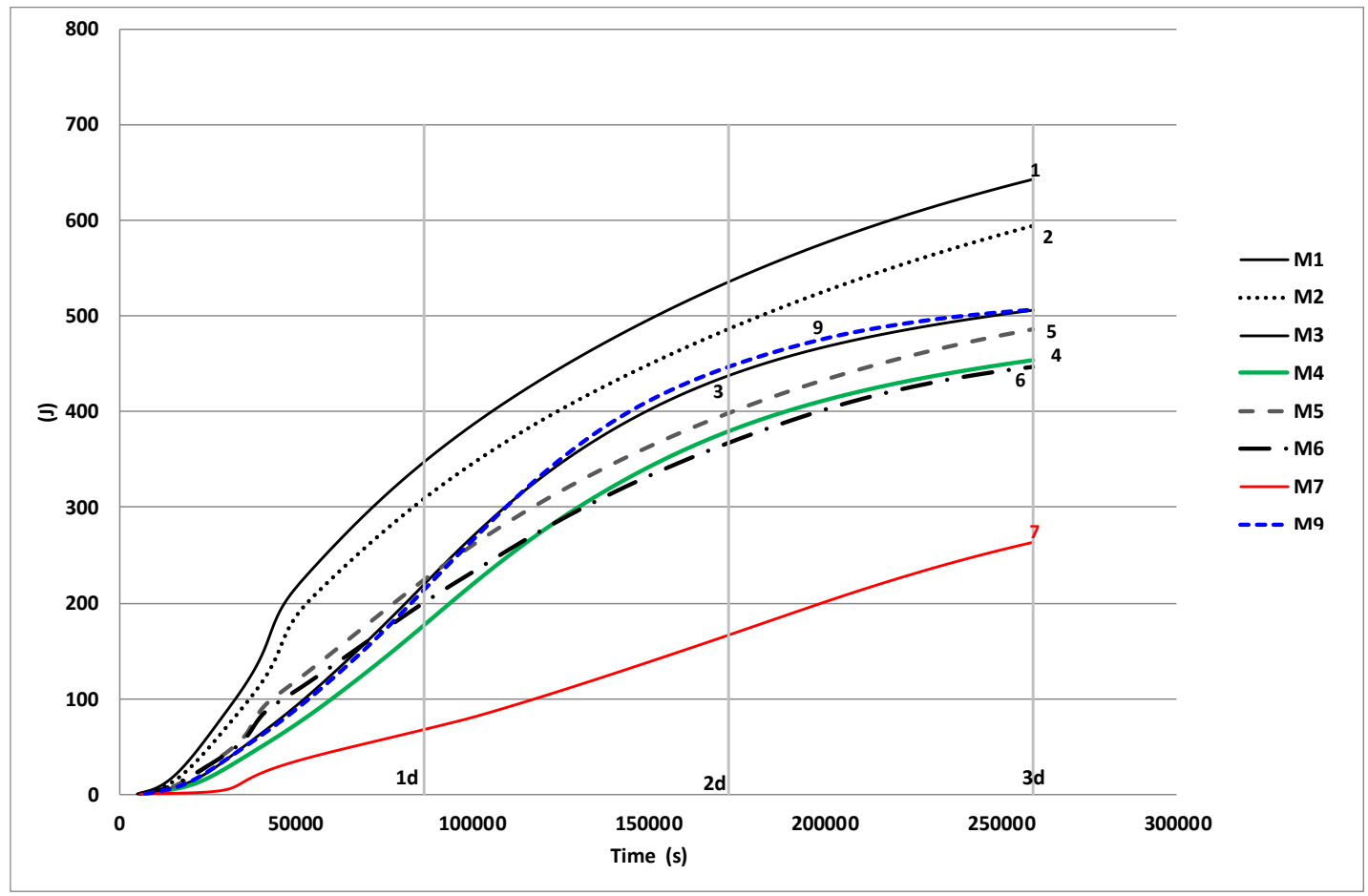

Fig. 14: Cumulative heat generation curves for first 3 days.

\subsubsection{2 pH measurements}

Fig. 15 summarises the results of $\mathrm{pH}$ and the nine mixes with different compositions of W/B, the percentages of cement, GGBS and ANH. It is shown that Supersulfated cements (SSCs) have lower $\mathrm{pH}$ values $(<12.5$ at all ages) than $\mathrm{PC}$, which has a $\mathrm{pH}$ of 13.9 [41], making SSC more preferable in essential applications such as nuclear waste encapsulation.

The figure shows that the $\mathrm{pH}$ value decreased with time for all samples between 1 and 7 days. Similar trend was observed in the majority of mixes between 7 and 28 days except for sample 2, 5 and 9 which showed slight increase in the $\mathrm{pH}$ values. This decrease refers to the consumption of ions in the pore structure due to the hydration process. 


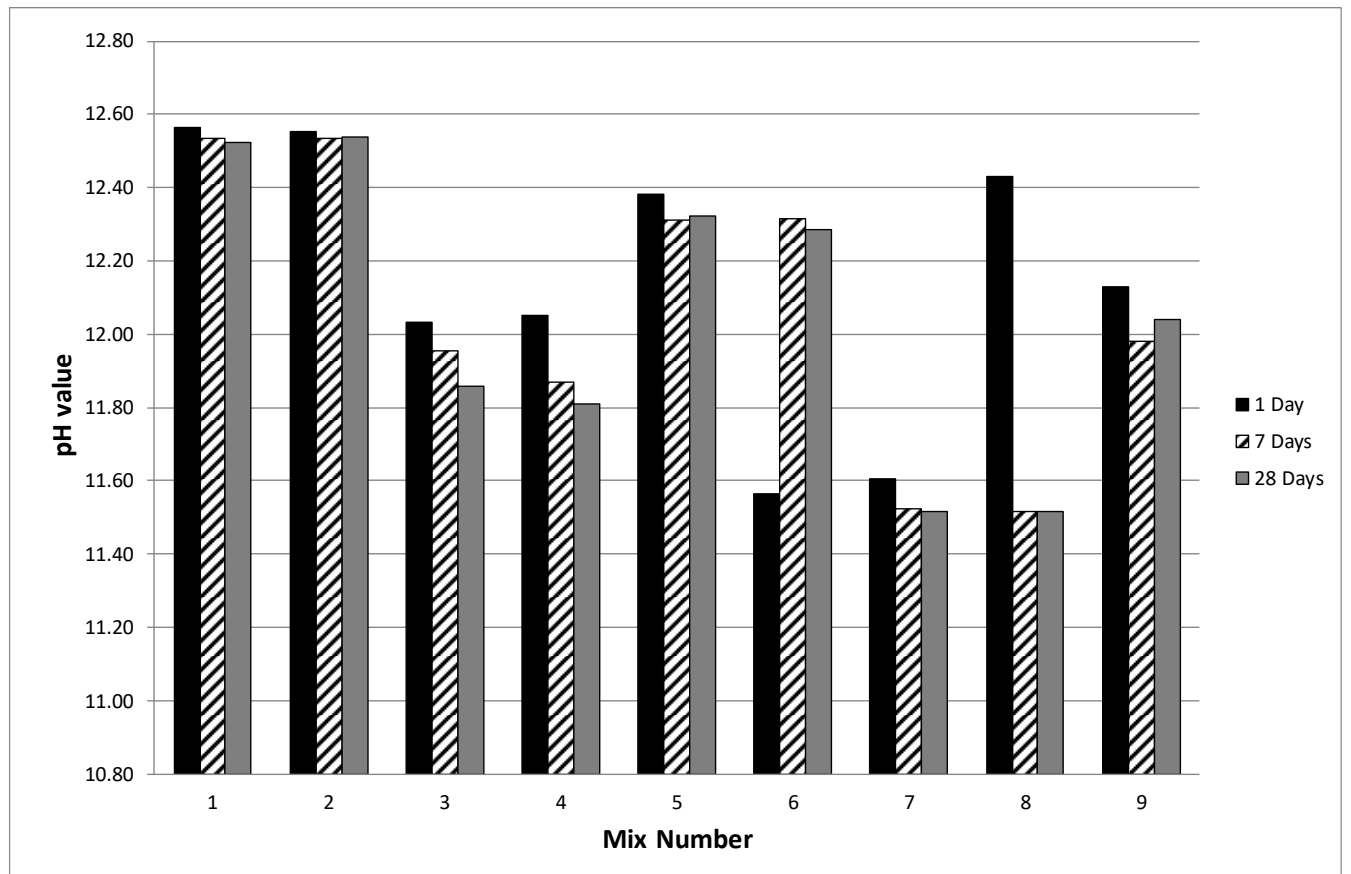

Fig. 15. Summary of pore solution $\mathrm{pH}$

The incorporation of ANH replacing the Portland cement (C) results in remarkable decrease in $\mathrm{pH}$ at all ages as introducing the $\mathrm{ANH}$ reduced the lower initial $\mathrm{pH}$. Likewise, the increase in the content of GGBS led to a decrease in the $\mathrm{pH}$ value of the pore structure as GGBS has lower initial $\mathrm{pH}$ than Portland cement. The increase of $\mathrm{W} / \mathrm{B}$ ratio decreased the $\mathrm{pH}$ value. This is in agreement with Collier [41] who found that increasing the w/b ratio from 0.5 to 0.6 increased the $\mathrm{pH}$ by I unit. This was attributed to the increased availability of water in the case of W/B of 0.6 allowing hydration of more cement powder, thereby releasing more hydroxide anions into solution. However, in this study, the W/B ratio did not show a significant effect on lowering the $\mathrm{pH}$. These results are in agreement with [42] which also found that decreasing the $\mathrm{pH}$ improved the bulk resistivity of SSC mixtures.

\subsubsection{SEM}

Figure 16 shows the SEM images of some mixes at various magnifications. The images clearly show the dense and compact structure of the cement after seven days. The dense structure was another requirement from the cement chosen to enclose the waste to prevent leaching. The microstructure consists mainly of $\mathrm{C}-\mathrm{S}-\mathrm{H}$, the main hydration product, and unhydrated slag grains. C-S-H is formed after the dissolution of slag grains when contacting the water and alkalis and then the ionic species saturate the solution and then precipitate as hydrated phases [8]. There were abundant grains of hydrated and partially hydrated slag grains, some small 
647 GGBS particles presented rims of reaction products (e.g. Mix 6-Figure 16 (f) and Mix 9-Figure 64816 (h)). It was found by [11] that the composition of the reaction rims around slag was similar 649 to that of the C-S-H from PC. However, [12] found that in the C-S-H of SSC is apparently 650 more foil like which is different than the fibrillar morphology of C-S-H in OPC. Mix 3 and 651 Mix 4 (Figure 16 (c) and (d) respectively) exhibits more micro voids in the micrsostructure 652 which could explain the low strength of these mixes compared to mix 1 and 2. Ettringite was 653 not detected. Ettringite is not the most abundant phase and it is not easy to detect in dried 654 polished samples because it is easily decomposed under the drying conditions of the vacuum 655 of the microscope column [11].

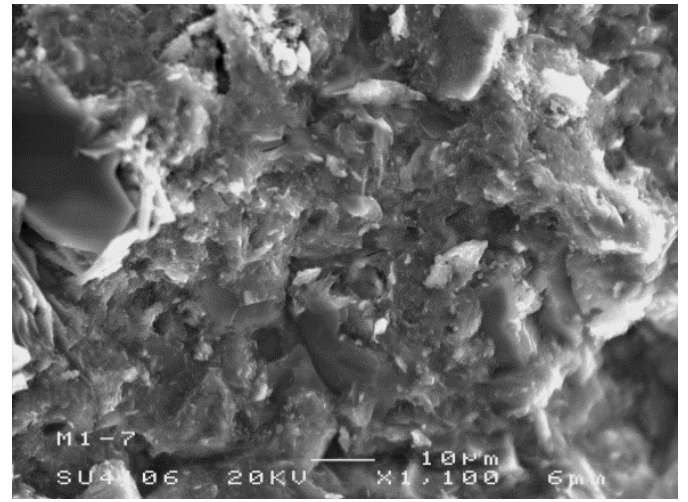

(a) Mix 1 image at 1,100 magnification

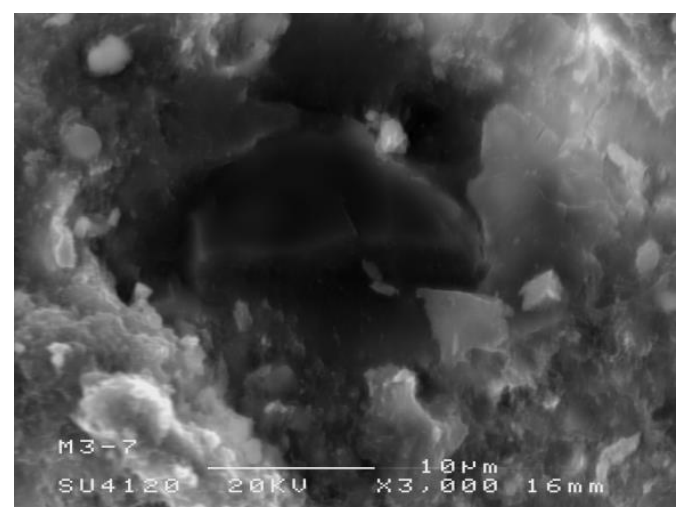

(c) Particle of unreacted slag, mix3, 7 days

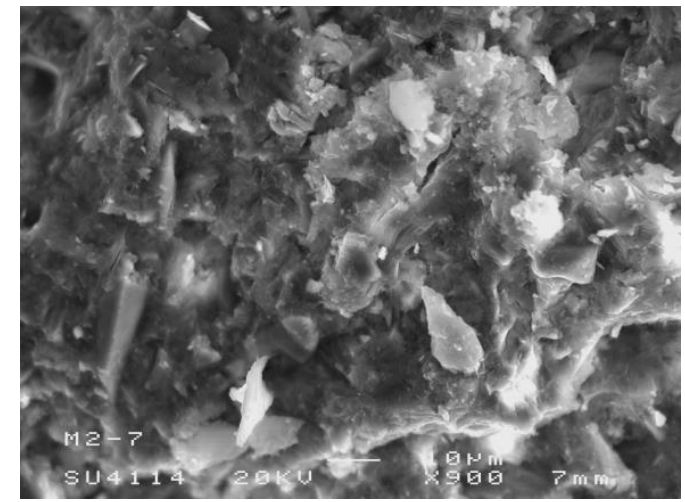

(b) Mix 2 image at 900 magnification.

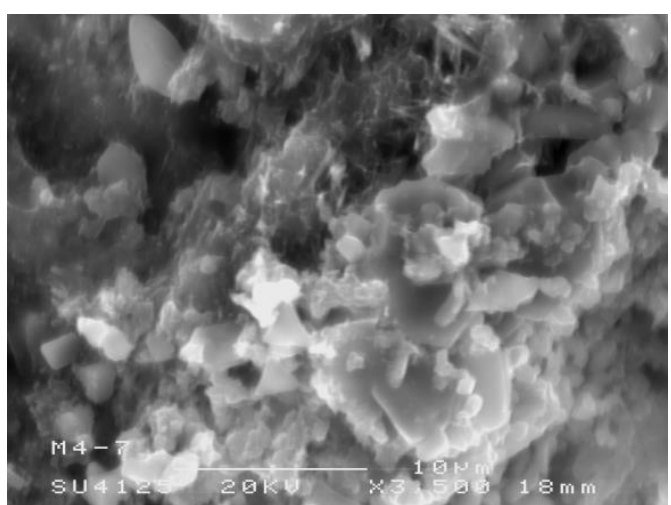

(d) An overall image of mix 4 at 7days showing CSH and BFS particles 


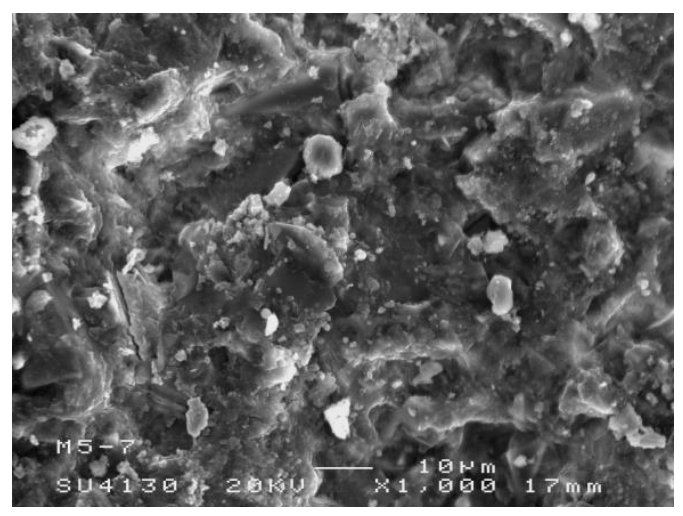

(e) Mix 5 image at 1100 magnification

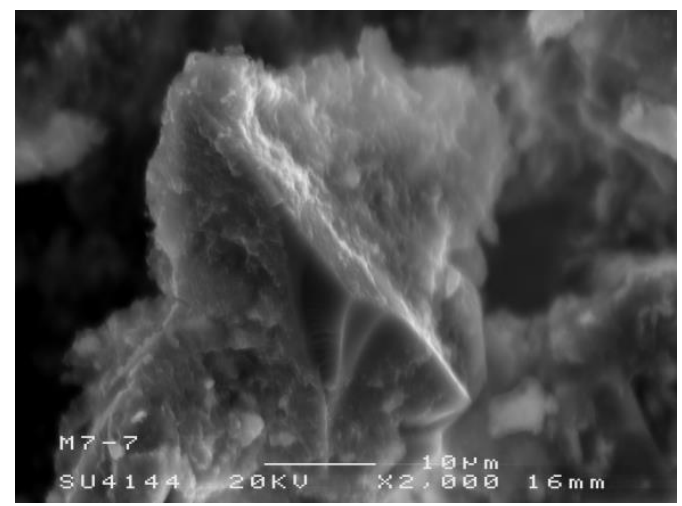

(g) Mix 7 image at 2000 magnification

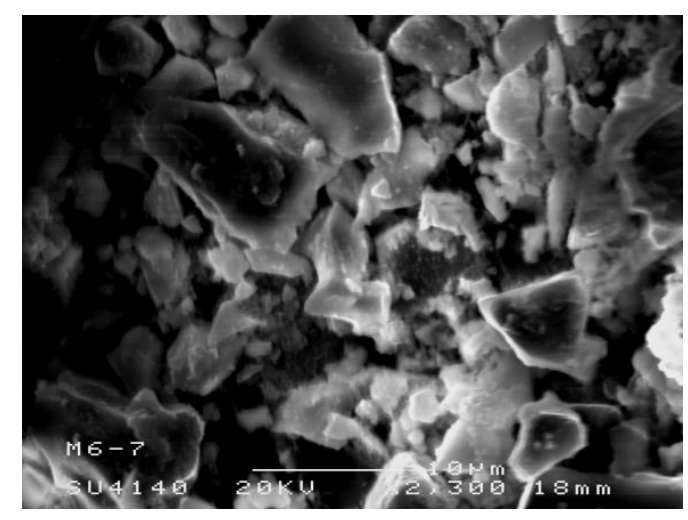

(f) Mix 6 image at 2300 magnification

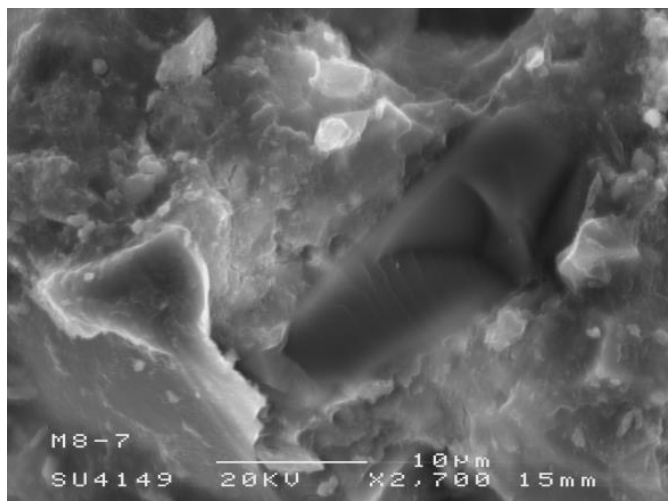

(h) Mix 9 image at 2700 magnification

Fig. 16. SEM results

657

658

659

660

661

662

663

664

665

666

667

\section{Conclusions}

The paper focused on optimizing the SSC cement grout in order to get the best of it. The effect of GGBS, W/B, and ANH dosages on the grout fluidity, rheological properties, induced bleeding, maximum heat of hydration and compressive strength was investigated using factorial design approach and analysis. The models derived in this study are valid for the experimental area corresponding to grout mixes made with variable levels of W/B, ANH and GGBS in the ranges of 0.34 to $0,44,0 \%$ to $20 \%$ by mass of binder, $60 \%$ to $80 \%$ by mass of binder, respectively. Based on the results from this study, the following conclusions are drawn:

- In comparison to GGBS and ANH, W/B ratio had more pronounced effects on the results of mini-slump, plate cohesion meter, Marsh cone time, yield stress, plastic viscosity, induced bleeding, permeability, compressibility, and compressive strength. 
- The increase in the dosage of GGBS led to an increase in the values of plate cohesion meter, Marsh cone time, yield stress and plastic viscosity, while reducing the mini-slump values, maximum hydration, and compressive strength. This is ascribed to the fine nature of GGBS particles and pozzolanic effect.

- While the ANH particles caused a decrease in the maximum of heat of hydration, it increased the induced bleeding, permeability and compressibility due to its dominant effect on increasing the dormant period and increasing the rates of solid sedimentation and induced bleeding water.

- Increasing the dosage of ANH in grout reduced the hydrations kinetic at early-age, and thus reduced the compressive strength at $1 \mathrm{~d}, 3 \mathrm{~d}$ and $7 \mathrm{~d}$. However, this effect diminished at later ages at $28 \mathrm{~d}$ in a manner similar to increasing W/B.

- The increase in the dosage of ANH led to an increase in the mini-slump values (fluidity), but a decrease in the values of yield stress, plastic viscosity, plate cohesion, and Marsh cone time. This is attributed to better deflocculation of particles at the fresh state.

- The increase of GGBS percentage delayed the reaction process and decreased the total heat after 3 days, while W/B slightly reduced the total heat it didn't significantly affect the reaction process.

- $\mathrm{pH}$ measurements in the present study confirmed the suitability of these mixture to low$\mathrm{pH}$ applications as the increase in both the GGBS and ANH markedly decreased the initial $\mathrm{pH}$, thereby lowering the $\mathrm{pH}$ at different ages.

- The modelling and prediction of the response of other points in the experimental domain were therefore possible. Although the models are based on a given set of materials, they can be easily used to generate future results using other materials.

- Dense microstructure was observed for mixes examined in this study. C-S-H is the main reaction product with presence of unreacted slag grains embedded well in the structure. However, some micro voids were observed in mixes containing ANH which led to lower compressive strength of mixes with ANH.

\section{CRediT authorship contribution statement}

M.Sonebi. and Y.Bai. did the conceptualization, and the design of investigation as well as performing the experiments. M.Sonebi. carried out the software analysis of the results and the 
visualization. M.Sonebi. A.Abdalqader, T. Fayyad, and A.Perrot. analysed the results and wrote the original draft and reviewed and edited the final version.

\section{Declaration of Competing Interest}

The authors declare that they have no known competing financial interests or personal relationships that could have appeared to influence the work reported in this paper.

\section{Acknowledgments}

The authors would like to express their gratitude to P. McCann from QUB and N. Collier from Eden Nuclear and Environment Ltd for their helps for some experiments.

\section{References}

1. Schneider M, Romer M, Tschudin M, Bolio H (2011) Sustainable cement productionpresent and future. Cement and Concrete Research 41:642-650. https://doi.org/10.1016/j.cemconres.2011.03.019

2. Madlool NA, Saidur R, Hossain MS, Rahim NA (2011) A critical review on energy use and savings in the cement industries. Renewable and Sustainable Energy Reviews 15:2042-2060. https://doi.org/10.1016/j.rser.2011.01.005

3. EN15743 (2015) BS EN 15743:2010+A1:2015 Supersulfated cement - Composition, specifications and conformity criteria. BSI

4. Khatib JM, Wright L, Mangat PS (2016) Mechanical and physical properties of concrete containing FGD waste. Magazine of Concrete Research 68:550-560.

https://doi.org/10.1680/macr.15.00092

5. Khatib JM, Mangat PS, Wright L (2008) Sulfate resistance of mortar containing simulated FGD waste. Proceedings of Institution of Civil Engineers: Construction Materials 161:119-128. https://doi.org/10.1680/coma.2008.161.3.119

6. (2020) Specifying Sustainable Concrete

7. Hewlett PC (2004) Lea's Chemistry of Cement and Concrete, fourth edi. Elsevier Science \& Technology Books, Oxford

8. Gruskovnjak A, Lothenbach B, Winnefeld F, et al (2008) Hydration mechanisms of super sulphated slag cement. Cement and Concrete Research 38:983-992. https://doi.org/10.1016/j.cemconres.2008.03.004

9. Grounds T, Nowell D V., Wilburn FW (2003) Resistance of supersulfated cement to strong sulfate solutions. Journal of Thermal Analysis and Calorimetry 72:181-190. https://doi.org/10.1023/A:1023928021602

10. Grounds T, Nowell D V., Wilburn FW (1995) The influence of temperature and different storage conditions on the stability of supersulphated cement. Journal of Thermal Analysis 45:385-394. https://doi.org/10.1007/BF02548772 
11. Bazaldúa-Medellín ME, Fuentes AF, Gorokhovsky A, Escalante-García JI (2015) Early and late hydration of supersulphated cements of blast furnace slag with fluorgypsum. Materiales de Construccion 65:e043. https://doi.org/10.3989/mc.2015.06013

12. Matschei T, Bellmann F, Stark J (2005) Hydration behaviour of sulphate-activated slag cements. Advances in Cement Research 17:167-178. https://doi.org/10.1680/adcr.2005.17.4.167

13. Richardson IG (2000) Nature of the hydration products in hardened cement pastes. Cement and Concrete Composites 22:97-113. https://doi.org/10.1016/S09589465(99)00036-0

14. Baux C, Phelipot-Mardelé A, Lanos C, et al (2013) PERFORMANCES OF SUPER SULFATED CEMENTS. In: International Conference on Concrete Under Severe Conditions. pp 1857-1870

15. Annabelle Phelipot-Mardelé, Gabriel Samson, Christophe Lanos (2015) Super sulfated cement: formulation and uses. In: Construction Materials ConMat. Whistler, Canada

16. Milestone NB (2006) Reactions in cement encapsulated nuclear wastes: need for toolbox of different cement types. Advances in Applied Ceramics 105:13-20. https://doi.org/10.1179/174367606X81678

17. Batchelor B (2006) Overview of waste stabilization with cement. Waste Management 26:689-698. https://doi.org/10.1016/J.WASMAN.2006.01.020

18. Zhang T, Cheeseman CR, Vandeperre LJ (2011) Development of low pH cement systems forming magnesium silicate hydrate (MSH). Cement and Concrete Research 41:439-442. https://doi.org/10.1016/j.cemconres.2011.01.016

19. Mobasher N, Bernal SA, Provis JL (2016) Structural evolution of an alkali sulfate activated slag cement. Journal of Nuclear Materials 468:97-104. https://doi.org/10.1016/J.JNUCMAT.2015.11.016

20. Wang J, Yu B, Gao Y (2014) Hydration Characteristics of Super Sulphated Cement with Different Fineness. In: Proceedings of the International Conference on Material and Environmental Engineering (ICMAEE 2014). Atlantis Press, Paris, France

21. Nägele E (1986) The Zeta-potential of cement: Part II: Effect of pH-value. Cement and Concrete Research 16:853-863. https://doi.org/10.1016/0008-8846(86)90008-6

22. Jain N, Civil MG-IJ of M and, 2015 U (2015) Formulation of Sulphate Resistant Super Sulphated Cement Using Fluorogypsum and Granulated Blast Furnace Slag. IOSR Journal of Mechanical and Civil Engineering (IOSR-JMCE) 12:153-159

23. Gao YX, Yu BY, Xu FL (2012) Effect of Modified Phosphogypsum on the Mechanical Properties of Super Sulphate Cement. Applied Mechanics and Materials 161:264-268. https://doi.org/10.4028/www.scientific.net/AMM.161.264

24. Kantro D (1980) Influence of Water-Reducing Admixtures on Properties of Cement Paste\&mdash;A Miniature Slump Test. Cement, Concrete and Aggregates 2:95-102. https://doi.org/10.1520/CCA10190J 
25. Svermova L, Sonebi M, Bartos PJM (2003) Influence of mix proportions on rheology of cement grouts containing limestone powder. Cement and Concrete Composites 25:737749. https://doi.org/10.1016/S0958-9465(02)00115-4

26. Sonebi M (2006) Rheological properties of grouts with viscosity modifying agents as diutan gum and welan gum incorporating pulverised fly ash. Cement and Concrete Research 36:1609-1618. https://doi.org/10.1016/J.CEMCONRES.2006.05.016

27. Nehdi M, Rahman M (2004) Effect of Geometry and Surface Friction of Test Accessory on Oscillatory Rheological Properties of Cement Pastes. ACI Materials Journal 101:416-424. https://doi.org/10.14359/13428

28. Khayat KH, Yahia A (1997) Effect of Welan Gum-High-Range Water Reducer Combinations on Rheology of Cement Grout. ACI Materials Journal 94:365-372. https://doi.org/10.14359/321

29. Lombardi G (1985) THE ROLE OF COHESION IN CEMENT GROUTING OF ROCK. In: Proceedings of Fifteenth Congress on Large Dams. International Commission on Large Dams. pp 235-261

30. Perrot A, Rangeard D, Picandet V, Mélinge Y (2013) Hydro-mechanical properties of fresh cement pastes containing polycarboxylate superplasticizer. Cement and Concrete Research 53:221-228. https://doi.org/10.1016/J.CEMCONRES.2013.06.015

31. Perrot A, Lecompte T, Khelifi H, et al (2012) Yield stress and bleeding of fresh cement pastes. Cement and Concrete Research 42:937-944. http://dx.doi.org/10.1016/j.cemconres.2012.03.015

32. Sonebi M, Perrot A (2019) Effect of mix proportions on rheology and permeability of cement grouts containing viscosity modifying admixture. Construction and Building Materials 212:687-697. https://doi.org/10.1016/j.conbuildmat.2019.04.022

33. Picandet V, Rangeard D, Perrot A, Lecompte T (2011) Permeability measurement of fresh cement paste. Cement and Concrete Research 41:330-338. https://doi.org/10.1016/J.CEMCONRES.2010.11.019

34. Perrot A, Rangeard D (2017) Effects of mix design parameters on consolidation behaviour of fresh cement-based materials. Materials and Structures 50:117. https://doi.org/10.1617/s11527-016-0988-0

35. Rangeard D, Perrot A, Picandet V, et al (2015) Determination of the consolidation coefficient of low compressibility materials: application to fresh cement-based materials. Materials and Structures 48:1475-1483. https://doi.org/10.1617/s11527-0140247-1

36. Massoussi N, Keita E, Roussel N (2017) The heterogeneous nature of bleeding in cement pastes. Cement and Concrete Research 95:108-116. https://doi.org/10.1016/J.CEMCONRES.2017.02.012

37. Montgomery D (2007) Design and Analysis of Experiments: Second Edition. John Wiley \& Sons 
38. Roussel N, Stefani C, Leroy R (2005) From mini-cone test to Abrams cone test: Measurement of cement-based materials yield stress using slump tests. Cement and Concrete Research 35:817-822. https://doi.org/10.1016/j.cemconres.2004.07.032

39. Mangat PS, Khatib JM, Wright L (2006) Optimum utilisation of FGD waste in blended binders. Proceedings of Institution of Civil Engineers: Construction Materials 159:119127. https://doi.org/10.1680/coma.2006.159.3.119

40. Khatib JM, Mangat PS, Wright L (2013) Early age porosity and pore size distribution of cement paste with flue gas desulphurisation (FGD) waste. Journal of Civil Engineering and Management 19:622-627. https://doi.org/10.3846/13923730.2013.793609

41. Collier NC, Milestone NB, Gordon LE, Ko SC (2014) The suitability of a supersulfated cement for nuclear waste immobilisation. Journal of Nuclear Materials 452:457-464. https://doi.org/10.1016/j.jnucmat.2014.05.078

42. Masoudi R (2018) Examining compositions, hydration mechanisms and properties of supersulfated cement for use in concrete by Examining compositions, hydration mechanisms and properties of supersulfated cement for use in concrete. University of Toronto 